\title{
Examining the impact of heterogeneous nitryl chloride production on air quality across the United States
}

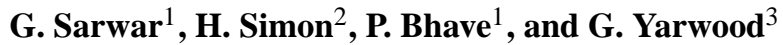 \\ ${ }^{1}$ National Exposure Research Laboratory, US Environmental Protection Agency, Research Triangle Park, NC, USA \\ ${ }^{2}$ Office of Air Quality Planning and Standards, US Environmental Protection Agency, Research Triangle Park, NC, USA \\ ${ }^{3}$ ENVIRON International Corporation, Novato, CA, USA
}

Correspondence to: G. Sarwar (sarwar.golam@epamail.epa.gov)

Received: 13 January 2012 - Published in Atmos. Chem. Phys. Discuss.: 27 February 2012

Revised: 8 June 2012 - Accepted: 4 July 2012 - Published: 24 July 2012

\begin{abstract}
The heterogeneous hydrolysis of dinitrogen pentoxide $\left(\mathrm{N}_{2} \mathrm{O}_{5}\right)$ has typically been modeled as only producing nitric acid. However, recent field studies have confirmed that the presence of particulate chloride alters the reaction product to produce nitryl chloride $\left(\mathrm{ClNO}_{2}\right)$ which undergoes photolysis to generate chlorine atoms and nitrogen dioxide $\left(\mathrm{NO}_{2}\right)$. Both chlorine and $\mathrm{NO}_{2}$ affect atmospheric chemistry and air quality. We present an updated gas-phase chlorine mechanism that can be combined with the Carbon Bond 05 mechanism and incorporate the combined mechanism into the Community Multiscale Air Quality (CMAQ) modeling system. We then update the current model treatment of heterogeneous hydrolysis of $\mathrm{N}_{2} \mathrm{O}_{5}$ to include $\mathrm{ClNO}_{2}$ as a product. The model, in combination with a comprehensive inventory of chlorine compounds, reactive nitrogen, particulate matter, and organic compounds, is used to evaluate the impact of the heterogeneous $\mathrm{CINO}_{2}$ production on air quality across the United States for the months of February and September in 2006. The heterogeneous production increases $\mathrm{ClNO}_{2}$ in coastal as well as many in-land areas in the United States. Particulate chloride derived from sea-salts, anthropogenic sources, and forest fires activates the heterogeneous production of $\mathrm{ClNO}_{2}$. With current estimates of tropospheric emissions, it modestly enhances monthly mean 8-h ozone (up to 1-2 ppbv or 3-4\%) but causes large increases (up to $13 \mathrm{ppbv}$ ) in isolated episodes. This chemistry also substantially reduces the mean total nitrate by up to $0.8-$ $2.0 \mu \mathrm{g} \mathrm{m}^{-3}$ or $11-21 \%$. Modeled $\mathrm{CINO}_{2}$ accounts for up to $6 \%$ of the monthly mean total reactive nitrogen. Sensitivity results of the model suggest that heterogeneous production of $\mathrm{ClNO}_{2}$ can further increase $\mathrm{O}_{3}$ and reduce $\mathrm{TNO}_{3}$ if elevated particulate-chloride levels are present in the atmosphere.
\end{abstract}

\section{Introduction}

Recent studies suggest that chlorine chemistry affects air quality in coastal and industrial areas of the United States (Chang et al., 2002; Knipping and Dabdub, 2003; Tanaka et al., 2003b; Chang and Allen, 2006; Sarwar and Bhave, 2007; Simon et al., 2009). These studies have evaluated the effects of naturally- and anthropogenically-derived chlorine on ozone $\left(\mathrm{O}_{3}\right)$. First, Knipping and Dabdub (2003) reported that chlorine released via heterogeneous reactions on seasalt particles can increase daily maximum $1-\mathrm{h} \mathrm{O}_{3}$ by up to 4 parts-per-billion (ppbv) in the Los Angeles area of California. Chang et al. (2002) and Chang and Allen (2006) concluded that industrial chlorine emissions increase $\mathrm{O}_{3}$ by up to $10-16 \mathrm{ppbv}$ in the Houston area of Texas. Finally, Sarwar and Bhave (2007) found that anthropogenic chlorine emissions increase daily maximum $8-\mathrm{h} \mathrm{O}_{3}$ by up to 4 ppbv in New York/New Jersey and 8 ppbv in the Houston areas.

In the past few years a new chlorine-containing species, nitryl chloride $\left(\mathrm{ClNO}_{2}\right)$, has been implicated as a major pathway for the production of reactive chlorine. Photolysis of $\mathrm{ClNO}_{2}$ generates chlorine atoms $(\mathrm{Cl})$ and nitrogen dioxide $\left(\mathrm{NO}_{2}\right)$; each can alter atmospheric chemistry and air quality. Finlayson-Pitts et al. (1989) first suggested that $\mathrm{ClNO}_{2}$ could be an intermediate between aqueous-phase chloride and gasphase chlorine radicals, but measurement technology did not exist to confirm this hypothesis in the ambient atmosphere. In the 2006 TEXAQS-II field study, Osthoff et al. (2008) measured atmospheric $\mathrm{ClNO}_{2}$ for the first time. They reported a peak value of greater than $1.0 \mathrm{ppbv}$ near Houston. Results of several other recent field campaigns also suggested the presence of relatively high levels of $\mathrm{ClNO}_{2}$ in coastal as well 
as in-land areas (Thornton et al., 2010; Mielke et al., 2010, 2011). These studies suggest that the main formation pathway for $\mathrm{ClNO}_{2}$ is heterogeneous hydrolysis of dinitrogen pentoxide $\left(\mathrm{N}_{2} \mathrm{O}_{5}\right)$ in the presence of particulate chloride. Simon et al. (2009) investigated the impact of measured $\mathrm{CINO}_{2}$ concentrations on $\mathrm{O}_{3}$ in Houston using the Comprehensive Air quality Model with extensions (CAMx) and reported that it can enhance $\mathrm{O}_{3}$ by up to $1.5 \mathrm{ppbv}$. While the Simon et al. (2009) study suggests $\mathrm{ClNO}_{2}$ can modestly affect $\mathrm{O}_{3}$ in Houston, little is known about the importance of $\mathrm{ClNO}_{2}$ in other areas and seasons. In the current study, we examine the impacts of the heterogeneous $\mathrm{ClNO}_{2}$ production on air quality in the United States using state-of-the-science knowledge about chlorine chemistry and a detailed inventory of chlorine emissions.

\section{Methodology}

\subsection{Model framework}

This study uses the Community Multiscale Air Quality (CMAQ) modeling system (version 5.0; beta version) (Binkowski and Roselle, 2003; Byun and Schere, 2006; Foley et al., 2010) to simulate air quality. This version of CMAQ includes several updates to the aerosol treatment including tracking of trace metals in fine particles and an updated inorganic partitioning module, ISORROPIA 2.1 (Fountoukis and Nenes, 2007). ISORROPIA 2.1 calculates equilibrium partitioning of inorganic compounds (chlorine, ammonia, nitrate, and water) between the gas and particle phases. This partitioning is dependent on ionic concentrations in the particles of $\mathrm{Na}^{+}, \mathrm{K}^{+}, \mathrm{Mg}^{2+}, \mathrm{Ca}^{2+}, \mathrm{NH}_{4}^{+}, \mathrm{Cl}^{-}, \mathrm{SO}_{4}^{2-}$, and $\mathrm{NO}_{3}^{-}$and gas-phase concentrations of $\mathrm{NH}_{3}, \mathrm{HNO}_{3}$, and $\mathrm{HCl}$. Evaluations for the CMAQ modeling system against ambient measurements have shown that CMAQ has considerable skill in simulating $\mathrm{O}_{3}$ and fine particles $\left(\mathrm{PM}_{2.5}\right)$ (Eder and Yu, 2006; Appel et al., 2007; Foley et al., 2010). The modeling domain covers the entire United States and consists of $299 \times 459$ horizontal grid-cells with a $12-\mathrm{km}$ resolution (see Fig. 1). The model contains 34 vertical layers with a surface layer height of approximately 40-m. Model simulations were performed for February and September in 2006. Boundary conditions were generated from the GEOS-CHEM model (Bey et al., 2001) results. CMAQ results from a previous model simulation are used as initial conditions for this work. To further minimize the impact of initial conditions on predicted results, the model simulation started five days prior to the actual simulation periods. Meteorological fields were obtained from the Weather Research and Forecasting (version 3.3) model (Skamarock et al., 2008).

\subsection{Emissions}

The 2005 National Emissions Inventory (http://www.epa. gov/ttn/chief/net/2005_nei_point.pdf) is used to generate model-ready emissions using the Sparse Matrix Operator Kernel Emission (SMOKE) (Houyoux et al., 2000). The Biogenic Emissions Inventory System (version 3.14) is used to compute biogenic emissions from soil and vegetation (Schwede et al., 2005). Emissions of molecular chlorine $\left(\mathrm{Cl}_{2}\right)$ and hydrochloric acid $(\mathrm{HCl})$ are included in the 2005 National Emissions Inventory. In addition, the fineparticulate emissions are speciated into the standard suite of compounds and trace elements (Reff et al., 2009). The largest sources of anthropogenic particulate chloride include paved and unpaved road dust, agricultural soil, wildfires, agricultural burning, coal/wood combustion, and diesel exhaust (Reff et al., 2009). Coarse particulate matter is also speciated to include particulate chloride. Road salt, one potentially important source of particulate chloride, is missing in the inventory. Fine and coarse sea-salt emissions (both openocean and surf-zone) are calculated in-line in CMAQ (Kelly et al., 2010).

\subsection{Gas-phase chlorine chemistry}

This study expands the CB05TU chemical mechanism (Whitten et al., 2010) to include additional chlorine chemistry. CB05TU builds on earlier work by Gery et al. (1989) and Yarwood et al. (2005) and includes 172 reactions involving 60 chemical species. These chemical mechanisms have been previously evaluated in the CMAQ model (Sarwar et al., 2008, 2011). Tanaka et al. (2003a) developed a chlorine mechanism consisting of 13 chemical reactions for use with an earlier version of this chemical mechanism. Here, we modify, and extend the chlorine mechanism of Tanaka et al. (2003a) for use with the CB05TU mechanism. Atmospheric reactions in the updated chlorine mechanism are shown in Table 1 (Reactions Cl1-Cl25). Rate constants for these reactions were updated using the recommendations from the International Union of Pure and Applied Chemistry (IUPAC) (Atkinson et al., 2005).

The new chlorine mechanism updates the chemistry developed by Tanaka et al. (2003a) in several ways. First, the chemistry is adjusted to new chemical species in the CB05TU mechanism. For example, the earlier mechanism grouped all aldehydes into a single lumped species, but the CB05TU mechanism splits acetaldehyde out from higher aldehydes. Similarly, the older mechanism included one olefin species, while the current mechanism separates compounds with internal carbon-carbon double bonds from those with a terminal carbon-carbon double bond (alk-1-enes). The new chlorine chemistry has been adjusted to account for these and other new species definitions.

The reactions of formaldehye, acetaldehyde, and higher aldehydes with $\mathrm{Cl}$ are similar to their reactions with $\mathrm{OH}$. The only exception is that the reaction with $\mathrm{Cl}$ produces $\mathrm{HCl}$ compared to $\mathrm{H}_{2} \mathrm{O}$ produced from reactions with $\mathrm{OH}$. The products of the reaction between higher aldehydes and $\mathrm{Cl}$ are 
Table 1. Reactions in the chlorine mechanism for use with the CB05 mechanism.

\begin{tabular}{|c|c|c|c|c|}
\hline No. & Reactants & Products & Rate expression $^{\mathrm{a}}$ & Ref \\
\hline $\mathrm{Cl1}$ & $\mathrm{Cl} 2$ & $2 * \mathrm{Cl}$ & Photolysis & $\mathrm{b}$ \\
\hline $\mathrm{Cl} 2$ & $\mathrm{HOCl}$ & $\mathrm{OH}+\mathrm{Cl}$ & Photolysis & $\mathrm{b}$ \\
\hline $\mathrm{Cl} 3$ & $\mathrm{ClNO} 2$ & $\mathrm{Cl}+\mathrm{NO}_{2}$ & Photolysis & $\mathrm{b}$ \\
\hline $\mathrm{Cl} 4$ & $\mathrm{OH}+\mathrm{HCl}$ & $\mathrm{Cl}+\mathrm{H}_{2} \mathrm{O}$ & $6.58 \times 10^{-13}(T / 300)^{1.16} e^{(58 / T)}$ & $\mathrm{c}$ \\
\hline $\mathrm{Cl} 5$ & $\mathrm{Cl}+\mathrm{O}_{3}$ & $\mathrm{ClO}+\mathrm{O}_{2}$ & $2.3 \times 10^{-11} e^{(-200 / T)}$ & $\mathrm{b}$ \\
\hline $\mathrm{Cl} 6$ & $\mathrm{ClO}+\mathrm{ClO}$ & $0.3 * \mathrm{Cl}_{2}+1.4 * \mathrm{Cl}+\mathrm{O}_{2}$ & $1.63 \times 10^{-14}$ & $\mathrm{~b}$ \\
\hline $\mathrm{Cl} 7$ & $\mathrm{ClO}+\mathrm{NO}$ & $\mathrm{Cl}+\mathrm{NO}_{2}$ & $6.4 \times 10^{-12} e^{(290 / T)}$ & $\mathrm{b}$ \\
\hline $\mathrm{Cl} 8$ & $\mathrm{ClO}+\mathrm{HO}_{2}$ & $\mathrm{HOCl}+\mathrm{O}_{2}$ & $2.7 \times 10^{-12} e^{(220 / T)}$ & $\mathrm{b}$ \\
\hline $\mathrm{C} 19$ & $\mathrm{Cl}+\mathrm{NO}_{2}$ & $\mathrm{ClNO}_{2}$ & $\begin{array}{l}k_{o}=1.8 \times 10^{-31}(\mathrm{~T} / 300)^{-2.0} \\
k_{\infty}=1.0 \times 10^{-10}(T / 300)^{-1.0} \\
F=0.6 \text { and } N=1.0\end{array}$ & $\mathrm{~b}$ \\
\hline $\mathrm{Cl10}$ & $\mathrm{Cl}+\mathrm{CH}_{4}$ & $\mathrm{HCl}+\mathrm{MEO} 2$ & $6.6 \times 10^{-12} e^{(-1240 / T)}$ & $\mathrm{b}$ \\
\hline Cl11 & $\mathrm{Cl}+\mathrm{ETHA}$ & $\mathrm{HCl}+0.991 * \mathrm{ALD} 2+0.991 * \mathrm{XO}_{2}+0.009 * \mathrm{XO}_{2} \mathrm{~N}+\mathrm{HO}_{2}$ & $8.3 \times 10^{-11} e^{(-100 / T)}$ & $\mathrm{b}$ \\
\hline $\mathrm{Cl12}$ & $\mathrm{Cl}+\mathrm{PAR}$ & $\begin{array}{l}\mathrm{HCl}+0.87 * \mathrm{XO}_{2}+0.13 * \mathrm{XO}_{2} \mathrm{~N}+0.11 * \mathrm{HO}_{2} \\
+0.06 * \mathrm{ALD} 2-0.11 * \mathrm{PAR}+0.76 * \mathrm{ROR}+0.05 * \mathrm{ALDX}\end{array}$ & $5.00 \times 10^{-11}$ & $\mathrm{~b}$ \\
\hline $\mathrm{Cl13}$ & $\mathrm{Cl}+\mathrm{ETH}$ & $\mathrm{FMCl}+2.0 * \mathrm{XO}_{2}+\mathrm{HO}_{2}+\mathrm{FORM}$ & $1.07 \times 10^{-10}$ & $\mathrm{~b}$ \\
\hline $\mathrm{Cl} 14$ & $\mathrm{Cl}+\mathrm{OLE}$ & $\mathrm{FMCl}+0.33 * \mathrm{ALD} 2+0.67 * \mathrm{ALDX}+2.0 * \mathrm{XO}_{2}+\mathrm{HO}_{2}-\mathrm{PAR}$ & $2.5 \times 10^{-10}$ & $\mathrm{~b}$ \\
\hline Cl15 & $\mathrm{Cl}+\mathrm{IOLE}$ & $\begin{array}{l}0.3 * \mathrm{HCl}+0.7 * \mathrm{FMCl}+0.45 * \mathrm{ALD} 2+0.55 * \mathrm{ALDX} \\
+0.3 * \mathrm{OLE}+0.3 * \mathrm{PAR}+1.7 * \mathrm{XO} 2+\mathrm{HO}_{2}\end{array}$ & $3.5 \times 10^{-10}$ & $\mathrm{~b}$ \\
\hline Cl16 & $\mathrm{Cl}+\mathrm{ISOP}$ & $0.15 * \mathrm{HCl}+\mathrm{XO}_{2}+\mathrm{HO}_{2}+0.85 * \mathrm{FMCl}+\mathrm{ISPD}$ & $4.3 \times 10^{-10}$ & $b, d$ \\
\hline $\mathrm{Cl17}$ & $\mathrm{OH}+\mathrm{FMCl}$ & $\mathrm{Cl}+\mathrm{CO}+\mathrm{H}_{2} \mathrm{O}$ & $5.0 \times 10^{-13}$ & $\mathrm{~b}$ \\
\hline Cl18 & $\mathrm{FMCl}$ & $\mathrm{Cl}+\mathrm{CO}+\mathrm{HO}_{2}$ & Photolysis & $\mathrm{b}$ \\
\hline Cl19 & $\mathrm{Cl}+\mathrm{FORM}$ & $\mathrm{HCl}+\mathrm{HO}_{2}+\mathrm{CO}$ & $8.2 \times 10^{-11} e^{(-34 / T)}$ & $\mathrm{b}$ \\
\hline $\mathrm{Cl} 20$ & $\mathrm{Cl}+\mathrm{ALD} 2$ & $\mathrm{HCl}+\mathrm{C}_{2} \mathrm{O}_{3}$ & $7.9 \times 10^{-11}$ & $\mathrm{~b}$ \\
\hline $\mathrm{Cl} 21$ & $\mathrm{Cl}+\mathrm{ALDX}$ & $\mathrm{HCl}+\mathrm{C}_{\mathrm{X}} \mathrm{O}_{3}$ & $1.3 \times 10^{-10}$ & $\mathrm{~b}$ \\
\hline $\mathrm{Cl} 22$ & $\mathrm{Cl}+\mathrm{MEOH}$ & $\mathrm{HCl}+\mathrm{HO}_{2}+\mathrm{FORM}$ & $5.5 \times 10^{-11}$ & $\mathrm{~b}$ \\
\hline $\mathrm{C} 123$ & $\mathrm{Cl}+\mathrm{ETOH}$ & $\mathrm{HCl}+\mathrm{HO}_{2}+\mathrm{ALD} 2$ & $8.2 \times 10^{-11} e^{(45 / T)}$ & $\mathrm{b}$ \\
\hline $\mathrm{Cl} 24$ & $\mathrm{Cl}+\mathrm{TOL}$ & $\mathrm{HCl}+0.88 * \mathrm{XO}_{2}+0.88 * \mathrm{HO}_{2}+0.12 * \mathrm{XO}_{2} \mathrm{~N}$ & $6.1 \times 10^{-11}$ & $\mathrm{e}$ \\
\hline $\mathrm{Cl} 25$ & $\mathrm{Cl}+\mathrm{XYL}$ & $\mathrm{HCl}+0.84 * \mathrm{XO}_{2}+0.84 * \mathrm{HO}_{2}+0.16 * \mathrm{XO}_{2} \mathrm{~N}$ & $1.2 \times 10^{-10}$ & $\mathrm{f}$ \\
\hline
\end{tabular}

${ }^{\text {a }}$ First order rate constants are in units of $\mathrm{s}^{-1}$, second order rate constants are in units of $\mathrm{cm}^{3}$ molecule ${ }^{-1} \mathrm{~s}^{-1}$. Temperatures $(T)$ are in Kelvin. Rate constants for Reaction (7) is described by the falloff expression of the form $k=\left\{k_{o}[M] /\left(1+k_{o}[M] / k_{\infty}\right)\right\} F^{z}$, where $Z=\left\{(1 / N)+\log _{10}\left[k_{o}[M] / k_{\infty}\right]^{2}\right\}^{-1}$, where $[M]$ is the total pressure in molecules cm ${ }^{-3}$, and $k_{o}, k_{\infty}, F$, and $N$ are indicated in table.

Ref: $\mathrm{b}=$ Atkinson et al. (2005); $\mathrm{c}=$ Bryukov et al. (2006); $\mathrm{d}=$ Fan and Zhang, 2004; $\mathrm{e}=$ Smith et al. (2002); $\mathrm{f}=$ Wallington et al. (1988).

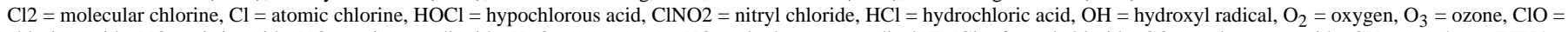

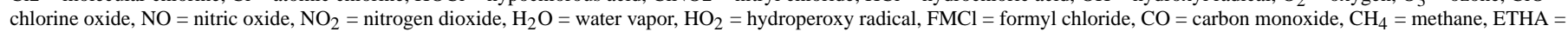

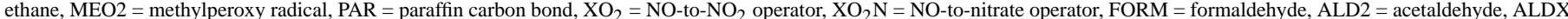

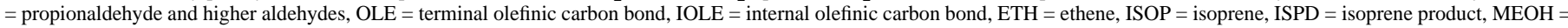
methanol, ETOH=ethanol, $\mathrm{C}_{2} \mathrm{O}_{3}=$ acetylperoxy radical, $\mathrm{C}_{\mathrm{X}} \mathrm{O}_{3}=$ higher acylperoxy radicals, $\mathrm{ROR}=$ secondary organic oxy radical, TOL $=$ toluene, $\mathrm{XYL}=\mathrm{xylene}$. The chlorine mechanism adds seven chemical species to CB05. 
uncertain because there may be hydrogen atom abstraction at the paraffinic carbon atoms of higher aldehydes.

Reaction products for terminal olefins with chlorine assume that reaction with the carbon-carbon double bond proceeds by addition, leading to cleavage of the double bond producing an acyl chloride (represented by formyl chloride) and an aldehyhyde (represented as $33 \%$ acetaldehyde and $67 \%$ higher aldehydes). The rate constant for the reaction between $\mathrm{Cl}$ and terminal olefins, Reaction (Cl14), is an average over the absolute rate constants for the alkenes presented in Tanaka et al. (2003a). The rate constant for the reaction of chlorine with internal olefins, Reaction (Cl15), is estimated as the rate constant for $\mathrm{Cl}$ reacting with a terminal olefin bond and two paraffin bonds. The products assume that reaction proceeds $70 \%$ by $\mathrm{Cl}$ addition to the $\mathrm{C}=\mathrm{C}$ bond and $30 \%$ by hydrogen atom abstraction from attached alkyl groups. $\mathrm{Cl}$ addition leads to cleavage of the double bond producing an acyl chloride (represented by formyl chloride) and an aldehyhyde (represented as $65 \%$ acetaldehyde and $35 \%$ higher aldehydes). The products for hydrogen atom abstraction pathway are assumed to be $\mathrm{HCl}$, higher aldehydes, and terminal olefins.

Second, the new chlorine chemistry includes more reactions of chlorine radicals with organic species including methanol, ethanol, aromatics, aldehydes, and ethane. In addition, the products from the existing reaction with chlorine and isoprene were modified to more explicitly track the fate of $\mathrm{Cl}$ and carbon from isoprene. The $\mathrm{HCl}$ and formyl chloride yields reflect the balance between hydrogen atom abstraction and addition pathways of $15 \%$ and $85 \%$ (Fan and Zhang, 2004). Formyl chloride serves as a surrogate for all products where chlorine is incorporated into a chlorocarbonyl after an addition reaction. Reaction of terpenes with $\mathrm{Cl}$ atoms is not included because the reaction products are too uncertain. Omitting the reaction may not greatly alter the fate of $\mathrm{Cl}$ atoms because $\mathrm{Cl}$ atoms react rapidly with all VOCs. For example, the global background for $\mathrm{CH}_{4}$ of about $1.8 \mathrm{ppm}$ (Oum et al., 1998) provides a significant "universal" sink for $\mathrm{Cl}$ atoms because $\mathrm{Cl}$ atoms react quite rapidly with $\mathrm{CH}_{4}$.

The next major update to the Tanaka et al. (2003a) work is the inclusion of new reactions that lead to the formation of chlorine radicals including $\mathrm{OH}$ oxidation of $\mathrm{HCl}$, Reaction (Cl4), and photolysis and oxidation of formyl chloride, Reactions (C118) and (C117). The new chemistry also includes both the gas-phase formation of $\mathrm{ClNO}_{2}$, Reaction (C19), and its subsequent photolysis, Reaction ( $\mathrm{Cl} 3)$, as described by (Atkinson et al., 2005). In total, the updated chlorine mechanism contains five sources of reactive gasphase $\mathrm{Cl}$ : photolysis of $\mathrm{Cl}_{2}, \mathrm{HOCl}$, and $\mathrm{ClNO}_{2}$, reaction of $\mathrm{HCl}$ with $\mathrm{OH}$, and the self-reaction of $\mathrm{ClO}$, Reactions (Cl1)(Cl4) and (Cl6).

Normalized photolysis rates were used by Tanaka et al. (2003a). In the updated chlorine chemistry, photolysis rates, $J,\left(\mathrm{~min}^{-1}\right)$ are directly calculated using the following general equation (Finlayson-Pitts and Pitts, 2000):

$J=\int_{\lambda_{1}}^{\lambda_{2}} \sigma(\lambda) \phi(\lambda) F(\lambda) d \lambda$

where, is $\sigma(\lambda)$ the absorption cross section $\left(\mathrm{cm}^{2}\right.$ molecule $\left.\mathrm{e}^{-1}\right), \quad \phi(\lambda)$ is the quantum yield (molecules photon $^{-1}$ ), $F(\lambda)$ is the actinix flux (photons $\mathrm{cm}^{2} \min ^{-1}$ ), $\lambda$ is the wavelength (nm). Quantum yield and absorption cross-section data from the recent IUPAC recommendations are used in the mechanism (Atkinson et al., 2005). Photolysis of $\mathrm{ClNO}_{2}$ can produce $\mathrm{Cl}$ and $\mathrm{NO}_{2}$ in the presence of sunlight via Reaction $(\mathrm{Cl} 3)$.

Finally, rate constants for several reactions described by Tanaka et al. (2003a), have been updated to meet the latest recommendations of IUPAC (Atkinson et al., 2005): the reaction of $\mathrm{Cl}$ with $\mathrm{O}_{3}$, Reaction $(\mathrm{Cl5})$; the reaction of $\mathrm{ClO}$ with $\mathrm{NO}$ and $\mathrm{HO}_{2}$ (Reactions Cl7-Cl8).

Chlorine chemistry affects $\mathrm{O}_{3}$ primarily via two competing pathways that consume and produce $\mathrm{O}_{3}$. It directly consumes $\mathrm{O}_{3}$ via Reaction $(\mathrm{Cl} 5)$. It also affects $\mathrm{O}_{3}$ via reactions initiated by $\mathrm{Cl}$ and VOCs. Chlorine chemistry can enhance the oxidation of VOCs which then produce additional peroxy radicals $\left(\mathrm{HO}_{2}\right.$ and $\left.\mathrm{RO}_{2}\right)$ : Reactions $(\mathrm{Cl10})-(\mathrm{Cl} 16)$ and (Cl18)-(Cl25) . The reaction of $\mathrm{NO}$ with $\mathrm{HO}_{2}$ and $\mathrm{RO}_{2}$ converts $\mathrm{NO}$ into $\mathrm{NO}_{2}$ and cause $\mathrm{O}_{3}$ production when $\mathrm{NO}_{2}$ is photolyzed (Finlayson-Pitts and Pitts, 2000):

$$
\begin{aligned}
& \mathrm{HO}_{2}+\mathrm{NO} \rightarrow \mathrm{HO}+\mathrm{NO}_{2} \\
& \mathrm{NO}_{2}+h v \rightarrow \mathrm{NO}+\mathrm{O}\left({ }^{3} \mathrm{P}\right) \\
& \frac{\mathrm{O}\left({ }^{3} \mathrm{P}\right)+\mathrm{O}_{2} \rightarrow \mathrm{O}_{3}}{\mathrm{HO}_{2}+\mathrm{O}_{2} \rightarrow \mathrm{OH}+\mathrm{O}_{3}} \\
& \mathrm{RO}_{2}+\mathrm{NO} \rightarrow \mathrm{RO}+\mathrm{NO}_{2}
\end{aligned}
$$

(R4: net result of R1 to R3)

If additional $\mathrm{O}_{3}$ production via Reactions (R1) and (R5) exceeds $\mathrm{O}_{3}$ consumption via Reaction $(\mathrm{Cl} 5) \mathrm{O}_{3}$ will increase.

\subsection{Heterogeneous reaction}

Although $\mathrm{ClNO}_{2}$ can be formed in the gas phase through Reaction (Cl9), the high nighttime $\mathrm{ClNO}_{2}$ concentrations observed in recent field campaigns are predominantly formed from reactions of $\mathrm{N}_{2} \mathrm{O}_{5}$ on particle surfaces. Current versions of CMAQ treat this heterogeneous $\mathrm{N}_{2} \mathrm{O}_{5}$ chemistry as producing only nitric acid, Reaction (R6).

$\mathrm{N}_{2} \mathrm{O}_{5}(\mathrm{~g})+\mathrm{H}_{2} \mathrm{O}(\mathrm{aq}) \rightarrow 2 \times \mathrm{HNO}_{3}(\mathrm{~g})$

CMAQv5.0 calculates the rate constant of Reaction (R6) $\left(k_{\mathrm{N}_{2} \mathrm{O}_{5} \text {, het }}\right)$ on fine PM using Eq. (2).

$k_{\mathrm{N}_{2} \mathrm{O}_{5}, \text { het }}=\left(\frac{\bar{d}}{2 D}+\frac{4}{\bar{c} \gamma}\right)^{-1} A$ 
In Eq. (2), $\bar{d}$ represents the effective diameter, $D$ represents the diffusivity of $\mathrm{N}_{2} \mathrm{O}_{5}$ in air (as a function of temperature and pressure), $\bar{c}$ is the mean molecular velocity of $\mathrm{N}_{2} \mathrm{O}_{5}$ (a function of temperature), A is the aerosol surface area concentration, and $\gamma$ is the reactive uptake coefficient defined as the probability that a collision between a $\mathrm{N}_{2} \mathrm{O}_{5}$ molecule and an aerosol particle will result in a reaction. The derivation of this equation is discussed in more detail elsewhere (Jacob, 2000). The CMAQ model calculates $\gamma \mathrm{N}_{2} \mathrm{O}_{5}$ as a complex function of temperature, relative humidity, particle composition, and phase state (Davis et al., 2008).

The recent studies of Bertram and Thornton (2009) and Roberts et al. (2009) show that when particles contain chloride, $\mathrm{ClNO}_{2}$ is also formed as a product, Reactions (R7)(R10).

$$
\begin{array}{ll}
\mathrm{N}_{2} \mathrm{O}_{5}(\mathrm{~g}) \leftrightarrow \mathrm{NO}_{3}^{-}(\mathrm{aq})+\mathrm{NO}_{2}^{+}(\mathrm{aq}) & \text { (R7) } \\
\mathrm{NO}_{3}^{-}(\mathrm{aq})+\mathrm{H}^{+}(\mathrm{aq}) \rightarrow \mathrm{HNO}_{3}(\mathrm{~g}) & (\mathrm{R} 8) \\
\mathrm{NO}_{2}^{+}(\mathrm{aq})+\mathrm{H}_{2} \mathrm{O} \rightarrow \mathrm{HNO}_{3}(\mathrm{~g})+\mathrm{H}^{+} & (\mathrm{R} 9) \\
\mathrm{NO}_{2}^{+}(\mathrm{aq})+\mathrm{Cl}^{-}(\mathrm{aq}) \rightarrow \mathrm{ClNO}_{2}(\mathrm{~g}) \\
----------- \\
\mathrm{N}_{2} \mathrm{O}_{5}+\mathrm{H}_{2} \mathrm{O} \rightarrow \mathrm{Y} \times\left(\mathrm{HNO}_{3}+\mathrm{ClNO}_{2}\right)+2 \times(1-Y) \mathrm{HNO}_{3}
\end{array}
$$

(R11: net result of R7-R10)

The yield of $\mathrm{ClNO}_{2}(Y)$ represents the likelihood of $\mathrm{NO}_{2}^{+}(\mathrm{aq})$ reacting via Reaction (R9) versus Reaction (R10). This yield depends on the molar concentrations of $\mathrm{Cl}^{-}(\mathrm{aq})$ present in the particle and has been parameterized by Bertram and Thornton (2009) and Roberts et al. (2009). Both suggested a similar correlation (Eq. 3):

$Y=\frac{1}{1+\frac{K_{9}\left[\mathrm{H}_{2} \mathrm{O}(1)\right]}{k_{10}\left[\mathrm{Cl}^{-}\right]}}$

where $\mathrm{H}_{2} \mathrm{O}(\mathrm{l})=$ particle liquid water, $\mathrm{Cl}^{-}=$particulate chloride, and $k_{9}$ and $k_{10}$ are the rate constants for Reactions (R9) and (R10). Bertram and Thornton (2009) derived a value of 483 for $k_{10} / k_{9}$ while Roberts et al. (2009) derived a value of 485 for $k_{10} / k_{9}$. The formation of $\mathrm{ClNO}_{2}$ in place of $\mathrm{HNO}_{3}$ has implications for the reactive nitrogen budget since $\mathrm{HNO}_{3}$ deposits quickly while $\mathrm{ClNO}_{2}$ does not. Consequently, an increase in $Y$ leads to increased availability of $\mathrm{NO}_{\mathrm{x}}$ which participates in photochemical $\mathrm{O}_{3}$ production outlined in Reactions (R1)-(R5).

Bertram and Thornton (2009) also suggested that the presence of particulate chloride can alter $\gamma_{\mathrm{N} 2 \mathrm{O} 5}$ and developed a correlation (Eq. 4).

$$
\gamma_{\mathrm{N}_{2} \mathrm{O}_{5}}=A k_{7 f}^{\prime}\left(1-\frac{1}{\left(\frac{k_{9}\left[\mathrm{H}_{2} \mathrm{O}(\mathrm{l})\right]}{k_{7}\left[\mathrm{NO}_{3}^{-}\right]}\right)+1+\left(\frac{K_{10}\left[\mathrm{Cl}^{-}\right]}{K_{7} b\left[\mathrm{NO}_{3}^{-}\right]}\right)}\right)
$$

where $\mathrm{H}_{2} \mathrm{O}(\mathrm{l})$ = particle liquid water, $\mathrm{NO}_{3}^{-}=$particulate nitrate, $\mathrm{Cl}^{-}=$particulate chloride, $k_{9} / k_{7 b}=6 \times 10^{-2}, k_{10} / k_{7 b}=$ $29, A=3.2 \times 10^{-8}$, and $k_{7 f}^{\prime}$ is calculated as follows:

$k_{7 f}^{\prime}=\beta-\beta e^{\left[-\delta\left[\mathrm{H}_{2} \mathrm{O}(1)\right]\right]}$

where, $\beta=1.15 \times 10^{-6}$, and $\delta=1.3 \times 10^{-1}$ (Bertram and Thornton, 2009).

In this study, we replace Reaction (R6) with Reaction (R11) in CMAQ. The yield and reaction rates are calculated separately for coarse and fine particles and use the chloride and water contents in the appropriately-size particles. The yield for Reaction (R11) is calculated with Eq. (3) on fine and coarse particles separately. Reactive uptake $\left(\gamma_{\left.\mathrm{N}_{2} \mathrm{O}_{5}\right)}\right.$ is calculated based on Davis et al. (2008) for fine particles (as is done in the base version of CMAQ) and is calculated based on Eq. (4) (using $k_{10} / k_{9}$ from Bertram and Thornton, 2009) for coarse particles. To conserve mass of chlorine, particulate chloride mass is reduced by the amount of chlorine in $\mathrm{ClNO}_{2}$ formed via the heterogeneous reaction on fine as well as coarse particles. Equilibrium between particulate chloride and gas-phase $\mathrm{HCl}$ is achieved quickly through the use of ISORROPIA 2.1 (Fountoukis and Nenes, 2007) in CMAQ, so the formation of $\mathrm{ClNO}_{2}$ can affect ambient concentrations of both particulate chloride and $\mathrm{HCl}$. If no particulate chloride is present, then $Y=0$ according to Eq. (3) and no $\mathrm{ClNO}_{2}$ is formed.

\subsection{Simulation details}

To evaluate the impacts of heterogeneous $\mathrm{ClNO}_{2}$ formation on air quality, two different simulations were completed. The base simulation was conducted with $Y=0$. Thus, only gasphase reactions produced $\mathrm{ClNO}_{2}$. The other simulation was conducted with yield calculated from Eq. (3) so that the heterogeneous hydrolysis of $\mathrm{N}_{2} \mathrm{O}_{5}$ produces $\mathrm{HNO}_{3}$ and $\mathrm{ClNO}_{2}$. Both the gas-phase and heterogeneous reactions produced $\mathrm{ClNO}_{2}$. Differences in the results obtained with the two simulations are attributed to the heterogeneous production of $\mathrm{ClNO}_{2}$.

\section{Results and discussion}

\subsection{Model performance without heterogeneous $\mathrm{CINO}_{2}$ production}

Model performance statistics for the base simulation without the heterogeneous $\mathrm{ClNO}_{2}$ production for 8-h daily maximum $\mathrm{O}_{3}$ and 24-h average $\mathrm{PM}_{2.5}$ are shown in Tables 2 and 3. Ambient monitoring data from the United States Environmental Protection Agency's Air Quality System (AQS) are used to evaluate $8-\mathrm{h} \mathrm{O}_{3}$. We show statistics both for all 8-h max $\mathrm{O}_{3}$ concentrations and for observed values above 65 ppbv to show how the model performs during high pollution episodes. The model captures observed 8-h $\mathrm{O}_{3}$ data 
Table 2. Model performance statistics for 8-h daily maximum $\mathrm{O}_{3}$.

\begin{tabular}{lccccc}
\hline & \multicolumn{2}{c}{ AQS } & & \multicolumn{2}{c}{ AQS (obs > 65 ppbv) } \\
\cline { 2 - 3 } \cline { 5 - 6 } & February & September & & February & September \\
\hline Number of observations & 14873 & 20019 & & 22 & 912 \\
Mean modeled (ppbv) & 39.5 & 49.8 & & 55.0 & 73.6 \\
Mean observed (ppbv) & 36.4 & 40.5 & & 69.0 & 73.7 \\
Median modeled (ppbv) & 40.8 & 48.8 & & 55.8 & 72.1 \\
Median observed (ppbv) & 37.1 & 39.2 & & 68.3 & 70.8 \\
NMB (\%) & 8.5 & 22.9 & & -20.2 & -0.1 \\
NME (\%) & 17.5 & 26.4 & & 20.2 & 11.8 \\
MB (ppb) & 3.1 & 9.2 & & -14.0 & -0.1 \\
ME (ppb) & 6.4 & 10.7 & & 14.0 & 8.7 \\
\hline NMB = Normalized Mean Bias, NME $=$ Normalized Mean Error, ME = Mean Error, MB = Mean Bias
\end{tabular}

Table 3. Model performance statistics for 24-h average $\mathrm{PM}_{2.5}$.

\begin{tabular}{|c|c|c|c|c|c|c|}
\hline & \multicolumn{2}{|c|}{ AQS FRM Sites } & \multicolumn{2}{|c|}{ IMPROVE } & \multicolumn{2}{|c|}{$\mathrm{CSN}$} \\
\hline & February & September & February & September & February & September \\
\hline Number of observations & 9553 & 5998 & 1348 & 831 & 949 & 628 \\
\hline Mean modeled $\left(\mu \mathrm{g} \mathrm{m}^{-3}\right)$ & 15.2 & 11.9 & 5.7 & 5.3 & 17.1 & 12.0 \\
\hline Mean observed $\left(\mu \mathrm{g} \mathrm{m}^{-3}\right)$ & 11.6 & 9.7 & 4.4 & 5.3 & 11.0 & 9.4 \\
\hline Median modeled $\left(\mu \mathrm{g} \mathrm{m}^{-3}\right)$ & 12.7 & 10.4 & 3.3 & 3.5 & 14.4 & 11.0 \\
\hline Median observed $\left(\mu \mathrm{g} \mathrm{m}^{-3}\right)$ & 9.8 & 8.3 & 2.9 & 4.0 & 11.0 & 8.8 \\
\hline NMB $(\%)$ & 31.1 & 22.8 & 33.2 & 0.0 & 28.0 & 28.1 \\
\hline $\operatorname{NME}(\%)$ & 52.6 & 38.9 & 56.1 & 41.7 & 51.8 & 45.0 \\
\hline $\operatorname{MB}\left(\mu \mathrm{g} \mathrm{m}^{-3}\right)$ & 3.8 & 2.2 & 1.4 & 0.0 & 3.8 & 2.6 \\
\hline $\operatorname{ME}\left(\mu \mathrm{g} \mathrm{m}^{-3}\right)$ & 6.1 & 3.8 & 2.4 & 2.2 & 6.9 & 4.2 \\
\hline
\end{tabular}

FRM $=$ Federal Reference Method

reasonably well. Model mean values are slightly greater than the observed values both in February and September. Ambient monitoring data from the AQS are used to evaluate daily mean $\mathrm{PM}_{2.5}$ levels measured by the Federal Referenced Method (FRM). In addition, daily mean $\mathrm{PM}_{2.5}$ levels from the Interagency Monitoring of PROtected Visual Environments (IMPROVE) network and the Chemical Speciation Network (CSN) are also used to evaluate the model results. The model captures observed $\mathrm{PM}_{2.5}$ levels at all monitoring networks both in February and September. Model performance statistics are similar to or better than those for the previous versions of the model (Eder and Yu, 2006; Appel et al., 2007; Foley et al., 2010).

Predicted mean fine-particulate chloride levels in the base simulation are shown in Fig. 1a-b. Fine particulate chloride concentrations are highest in coastal areas and the mid-west. In addition, fine particulate chloride is present in the entire eastern half of the United States in February and in Idaho in September. The fine particulate chloride in the eastern United States is largely derived from anthropogenic sources (mostly fugitive dust), while fine particulate chloride in the coastal areas comes mostly from sea salt. The high modeled levels in
Idaho in September are due to particulate chloride emissions from a large wildfire. While the magnitudes of predicted concentrations are greater in September, predicted particulate chloride in February is present over a larger geographical area. Predicted mean coarse particulate chloride levels without the heterogeneous $\mathrm{ClNO}_{2}$ production are shown in Fig. 1c-d.

Predicted fine particulate chloride levels averaged across all measurement sites in the United States are compared to the observed data from IMPROVE in Fig. 1e-f. With the exception of a few days in early February, average predictions are in good agreement with average observed data. Previous studies using the Tanaka et al. (2003a) chlorine chemistry and no $\mathrm{ClNO}_{2}$ formation also showed reasonable performance of particulate chloride predictions. Kelly et al. (2010) compared CMAQ predictions to size resolved (both fine and coarse particles) particulate chloride observations from three coastal monitoring sites in Florida and reported good agreement between the model predictions and the observed data. Bhave and Appel (2009) compared CMAQ predictions to size resolved (both fine and coarse particles) particulate chloride observations from multiple monitoring sites in the 

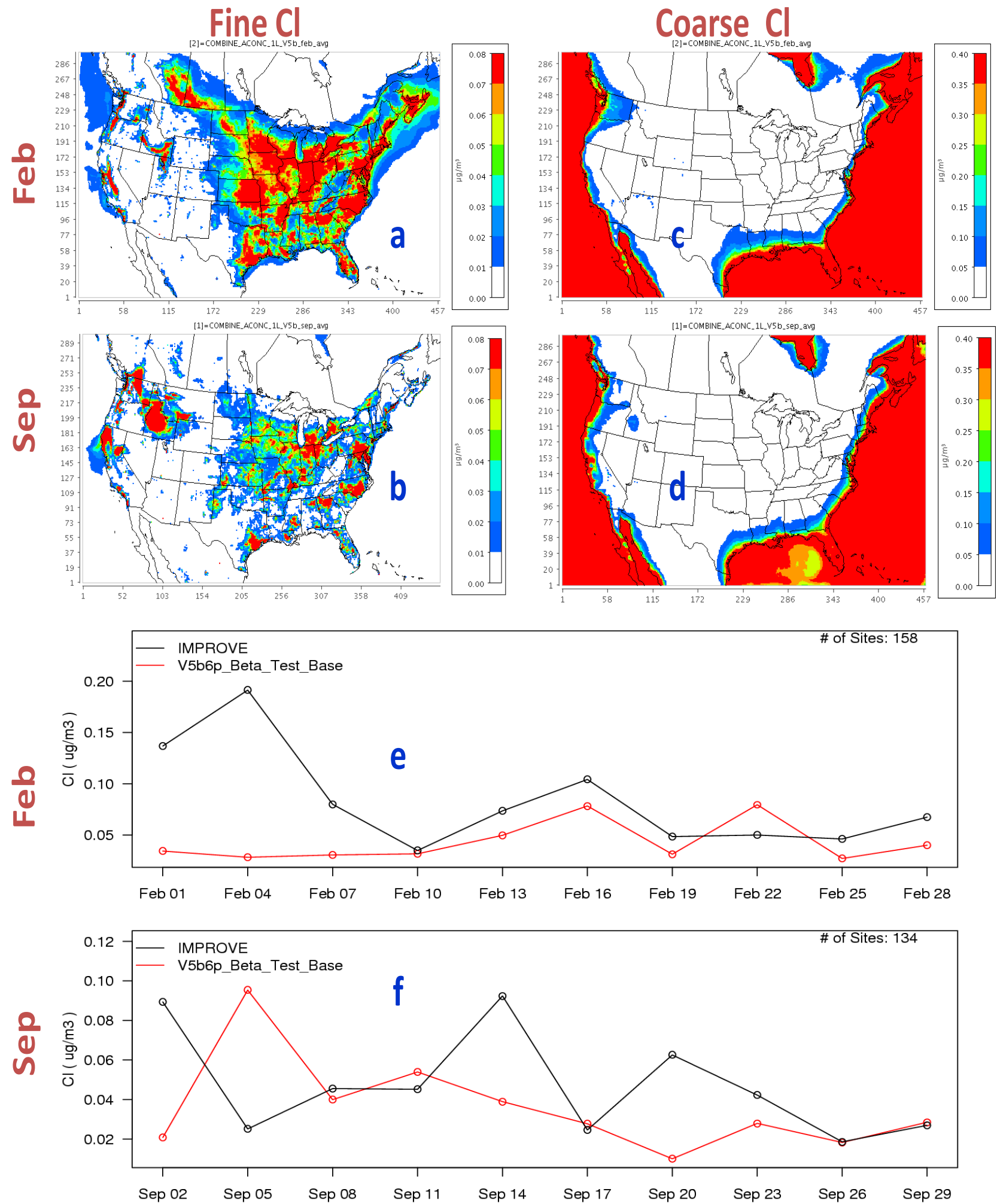

Fig. 1. Predicted mean fine particulate chloride $\left(\mu \mathrm{g} \mathrm{m}^{-3}\right)$ without the heterogeneous $\mathrm{ClNO}_{2}$ production in (a) February and (b) September. Predicted mean coarse particulate chloride $\left(\mu \mathrm{g} \mathrm{m}^{-3}\right)$ without the heterogeneous $\mathrm{ClNO}_{2}$ production in (c) February and (d) September. A comparison of predicted fine particulate chloride with observed data from the Interagency Monitoring of PROtected Visual Environments (IMPROVE) network in (e) February and (f) September. 
United States and also reported good agreement. These results suggest model predicted fine and coarse particulate chloride levels are in good enough agreement with observed data to be used to examine the impact of heterogeneous $\mathrm{ClNO}_{2}$ production on air quality.

\subsection{Impact of heterogeneous $\mathrm{ClNO}_{2}$ chemistry on model performance statistics}

The heterogeneous production of $\mathrm{ClNO}_{2}$ marginally affects model performance statistics for daily maximum $8-\mathrm{h} \mathrm{O}_{3}$. For example, it changed the Normalized Mean Bias (NMB) (Eder and Yu, 2006) from $-20.2 \%$ to $-18.8 \%$ in February and $0.1 \%$ to $0.4 \%$ in September for observed values above 65 ppbv. These changes which are mapped in Fig. S1 show that improvements and degradations in model performances do not have a noticeable geographic pattern. The inclusion of heterogeneous $\mathrm{ClNO}_{2}$ formation also changed Normalized Mean Error (NME) (Eder and Yu, 2006) both in February and September by similar margins.

Predicted weekly average total nitrate $\left(\mathrm{TNO}_{3}\right)$ is compared with observed data from the Clean Air Status and Trends Network (CASTNet). Predicted $\mathrm{TNO}_{3}$ without the heterogeneous production is greater than the observed data with NMB of $61.1 \%$ in February and $89.5 \%$ in September. Previous studies also reported over-predictions of nitrate (Foley et al., 2010). The over-predictions may be partially due to the $\gamma_{\mathrm{N}_{2} \mathrm{O}_{5}}$ parameterization used in the model. Brown et al. (2006) measured $\gamma_{\mathrm{N}_{2}} \mathrm{O}_{5}$ values in the eastern United States and reported the values to be much lower than those derived from current $\gamma_{\mathrm{N}_{2}} \mathrm{O}_{5}$ parameterizations available in the peerreviewed literature. Coatings of particles by organic materials have been suggested to lower $\gamma_{\mathrm{N}_{2}} \mathrm{O}_{5}$ values (Anttilla et al., 2006; Chang et al., 2011). However, the effect of organic particles on $\gamma_{\mathrm{N}_{2} \mathrm{O}_{5}}$ is not included in the current CMAQ model. The heterogeneous production of $\mathrm{ClNO}_{2}$ reduced the NMB to $57.1 \%$ in February and $85.9 \%$ in September for $\mathrm{TNO}_{3}$ in the CASTNet. The heterogeneous production of $\mathrm{CINO}_{2}$ reduced the NMB from $64.2 \%$ to $61.2 \%$ in February and $42.1 \%$ to $36.4 \%$ in September for 24 -h average $\mathrm{PM}_{2.5} \mathrm{ni}-$ trate in the IMPROVE network. It also reduced the NMB from $44.8 \%$ to $41.7 \%$ in February and $67.7 \%$ to $60.5 \%$ in September for 24-h average $\mathrm{PM}_{2.5}$ nitrate in the CSN. These improvements are shown in Fig. S2, S3, S4, and S5 and are most pronounced in the eastern US in February where observed total nitrate concentrations are highest.

\subsection{Predicted $Y, \mathrm{ClNO}_{2}$ levels, and comparison with ob- served $\mathrm{CINO}_{2}$}

Predicted mean values of $Y$ on fine and coarse particles with the heterogeneous $\mathrm{ClNO}_{2}$ production are presented in Fig. 2. As might be expected from Eq. (3), calculated yield is largest in areas in which particulate chloride concentrations are highest. Modeled yields on fine particles reached values above 0.7 in some coastal and in-land areas. Yield values on coarse particles reached 1.0 over the Gulf and the Oceans and ranged between 0.5 and 0.8 in coastal and between 0 and 0.4 for in-land areas. These modeled yields suggest that the presence of particulate chloride can efficiently activate the heterogeneous $\mathrm{ClNO}_{2}$ production pathway throughout large areas of the United States. Thornton et al. (2010) calculated annual average $\mathrm{ClNO}_{2}$ yield over the contiguous US by using a coarse grid-resolution $\left(1^{0} \times 1^{0}\right)$ and constraining their predictions with observations from the IMPROVE and the National Atmospheric Deposition Program. We calculate monthly averaged values for fine as well as coarse particles over the contiguous US by using a finer grid-resolution (12$\mathrm{km} \times 12-\mathrm{km}$ ). Thus, these values cannot be directly compared, so a qualitative comparison of these yields is made. Our predicted values are consistent with the calculation of Thornton et al. (2010) over the coastal areas; both studies suggest relatively higher values over the coastal areas in the US. While our study suggests values can be high in the entire eastern US in February (fine particles), Thornton et al. (2010) calculates higher values only in the southeastern US. Thornton et al. (2010) also suggests higher values throughout the western US while our study finds higher values over much of the West, but very low yields in the desert southwest.

Modeled mean of daily maximum $\mathrm{ClNO}_{2}$ levels in the base simulation that included only the gas-phase formation pathway (no heterogeneous $\mathrm{ClNO}_{2}$ production) were negligible (generally $<5$ pptv) and are not discussed further. Heterogeneous production enhanced $\mathrm{ClNO}_{2}$ levels both in February and September. The predicted monthly mean of daily 1-h $\mathrm{ClNO}_{2}$ maximum and the highest daily maximum $\mathrm{ClNO}_{2}$ levels with the heterogeneous production are presented in Fig. 3. $\mathrm{ClNO}_{2}$ formed where particulate chloride and $\mathrm{NO}_{\mathrm{x}}$ concentrations are prevalent. The highest mean daily maximum $\mathrm{ClNO}_{2}$ was found in the Los Angeles area both in February ( $\sim 1.0 \mathrm{ppbv})$ and in September ( $\sim 1.5 \mathrm{ppbv})$. Monthly average of daily maximum $\mathrm{ClNO}_{2}$ concentrations also reached values of 0.24 to $0.48 \mathrm{ppbv}$ in portions of the northeast during both September and February. While predicted values reached higher concentrations in September, predicted levels are more spatially distributed in February. The maximum hourly predicted value in February reached almost 3.0 ppbv in Los Angeles and 2.0 ppbv in the Midwest. High hourly $\mathrm{ClNO}_{2}$ concentrations in September were found in Idaho (4.5 ppbv maximum) and in Los Angeles (4.0 ppbv maximum). Predicted $\mathrm{ClNO}_{2}$ levels were consistently high in Los Angeles both in February and September. Available chlorine to produce $\mathrm{ClNO}_{2}$ in coastal areas comes from seasalt emissions and in the Midwest comes from anthropogenic chloride emissions. In addition, chlorine available to enhance $\mathrm{ClNO}_{2}$ over the eastern half of the United States in February is due to anthropogenic emissions and over Idaho is due to chorine emissions from the forest fires in September 2006.

Vertical profiles of $\mathrm{ClNO}_{2}$ and its main precursors $\left(\mathrm{N}_{2} \mathrm{O}_{5}\right.$ and particulate chloride) are examined for one day before 

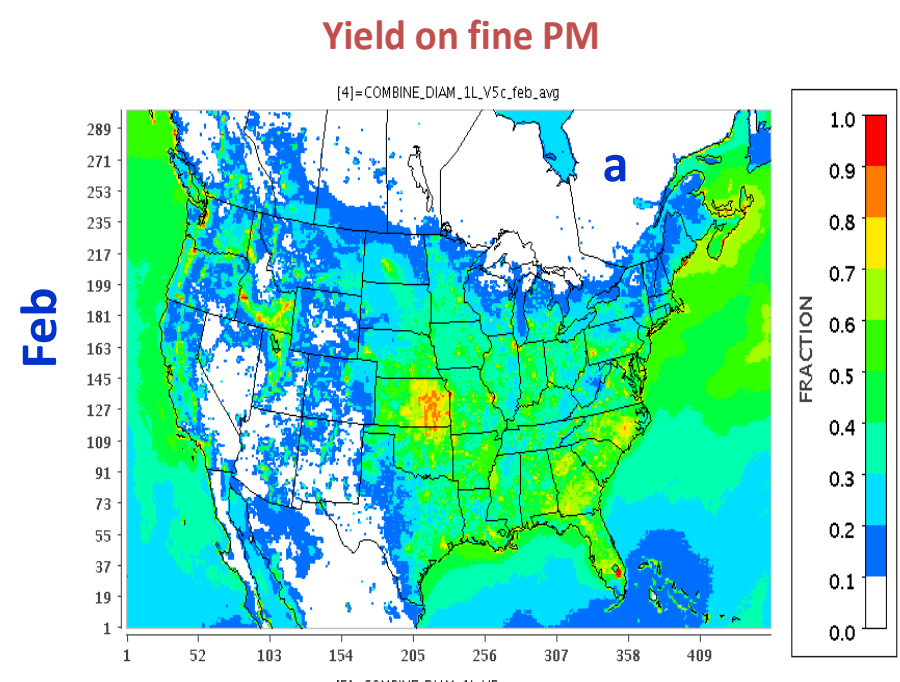

\section{Yield on coarse PM}
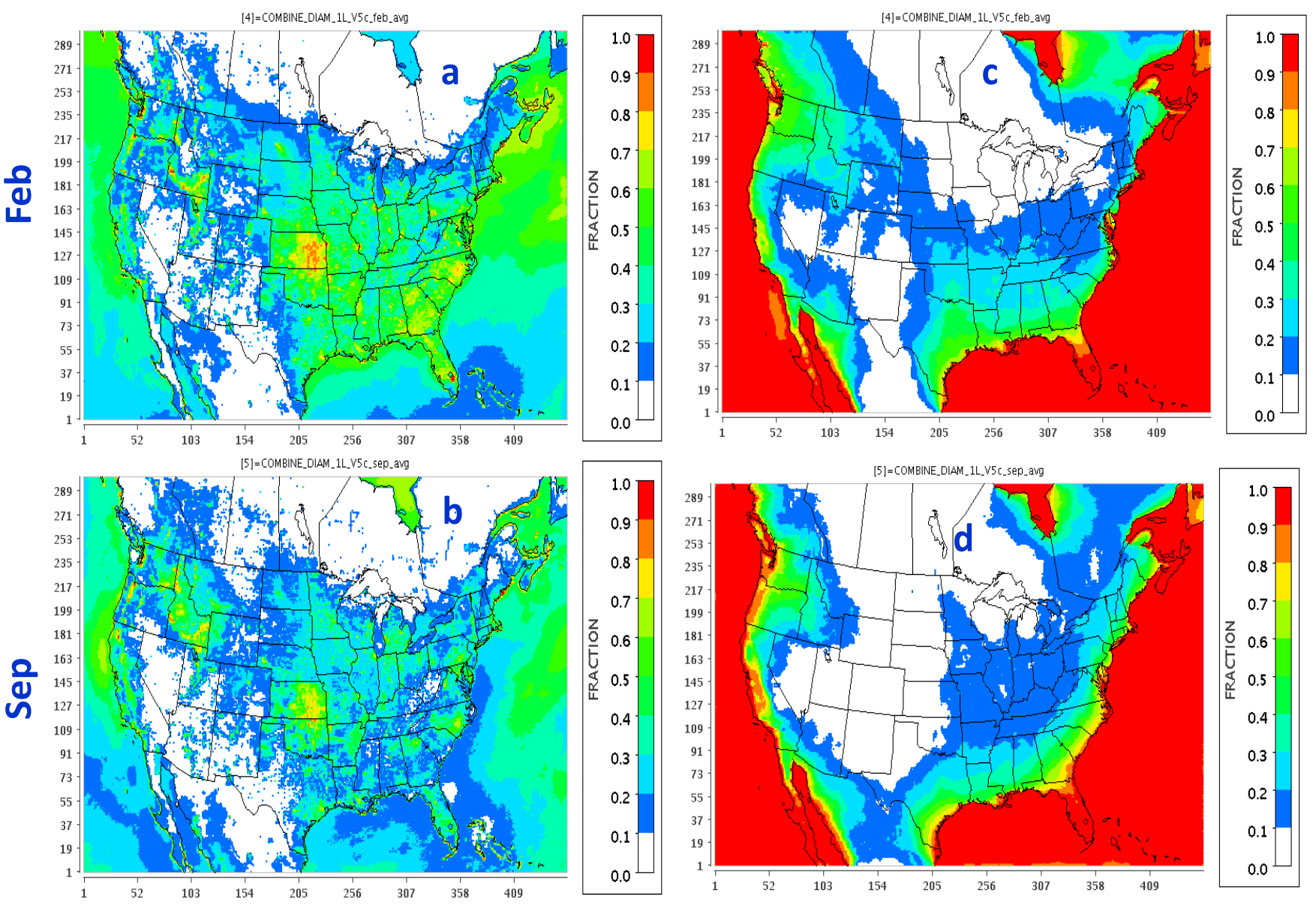

Fig. 2. (a) Predicted mean yield for $\mathrm{ClNO}_{2}$ on fine particles in (a) February and (b) September. Predicted mean yield for $\mathrm{ClNO}_{2}$ on coarse particles in (c) February and (d) September.

sunrise in February and one day in September at a few locations with high $\mathrm{ClNO}_{2}$ concentrations: Los Angeles and Indiana in February; Los Angeles and Idaho in September. The profiles shown in Fig. 4 are average concentrations over the identified regions and represent mean values over hundreds of square $\mathrm{km}$. These vertical profiles reveal some interesting relationships between $\mathrm{ClNO}_{2}$ and its precursors at these times and locations. All four instances shown in Fig. 4 display that $\mathrm{ClNO}_{2}$ concentrations are highest at the surface. Variation in the nighttime boundary layer height by location and season is demonstrated by $\mathrm{ClNO}_{2}$ being concentrated in the lowest $40 \mathrm{~m}$ of atmosphere in Los Angeles on 9 February 2006, but being mixed up to a height of $200-400 \mathrm{~m}$ in both locations on 12 September 2006. In contrast to $\mathrm{ClNO}_{2}$, $\mathrm{N}_{2} \mathrm{O}_{5}$ appears to peak in the residual layer aloft at between 200 and $400 \mathrm{~m}$ depending on the location and season. The exception to this is the Idaho location on 12 September 2006, where $\mathrm{N}_{2} \mathrm{O}_{5}$ is mostly depleted at all heights. Since the Idaho $\mathrm{ClNO}_{2}$ concentrations are associated with a large fire plume, it is possible that the loss of $\mathrm{N}_{2} \mathrm{O}_{5}$ by the end of the night was a result of large amounts particulate surface area available for hydrolysis reactions. In all four examples shown here, the vertical profiles of $\mathrm{ClNO}_{2}$ appear to mirror the profiles of particulate chloride suggesting that chlorine probably limits $\mathrm{ClNO}_{2}$ formation aloft, especially given the elevated $\mathrm{N}_{2} \mathrm{O}_{5}$ concentrations above the boundary layer. These plots also demonstrate that the chlorine may come from either fine or coarse particulate chloride since the Los Angeles profiles show very little fine chloride while the Indiana profile demonstrates a predominance of fine chloride over coarse chloride.

Ambient $\mathrm{ClNO}_{2}$ levels are not routinely measured; these measurements are conducted only in specialized field campaigns. To our knowledge, four sets of measurements have been published in the peer-reviewed literature. A qualitative comparison of predicted $\mathrm{ClNO}_{2}$ levels with these measurements is presented in Table 4. Osthoff et al. (2008) measured $\mathrm{ClNO}_{2}$ in Houston in 2006 and reported a peak value of about 1200 pptv. Predicted peak $\mathrm{ClNO}_{2}$ in Houston reached to 2000 pptv in February and 1500 pptv in September. Thornton 

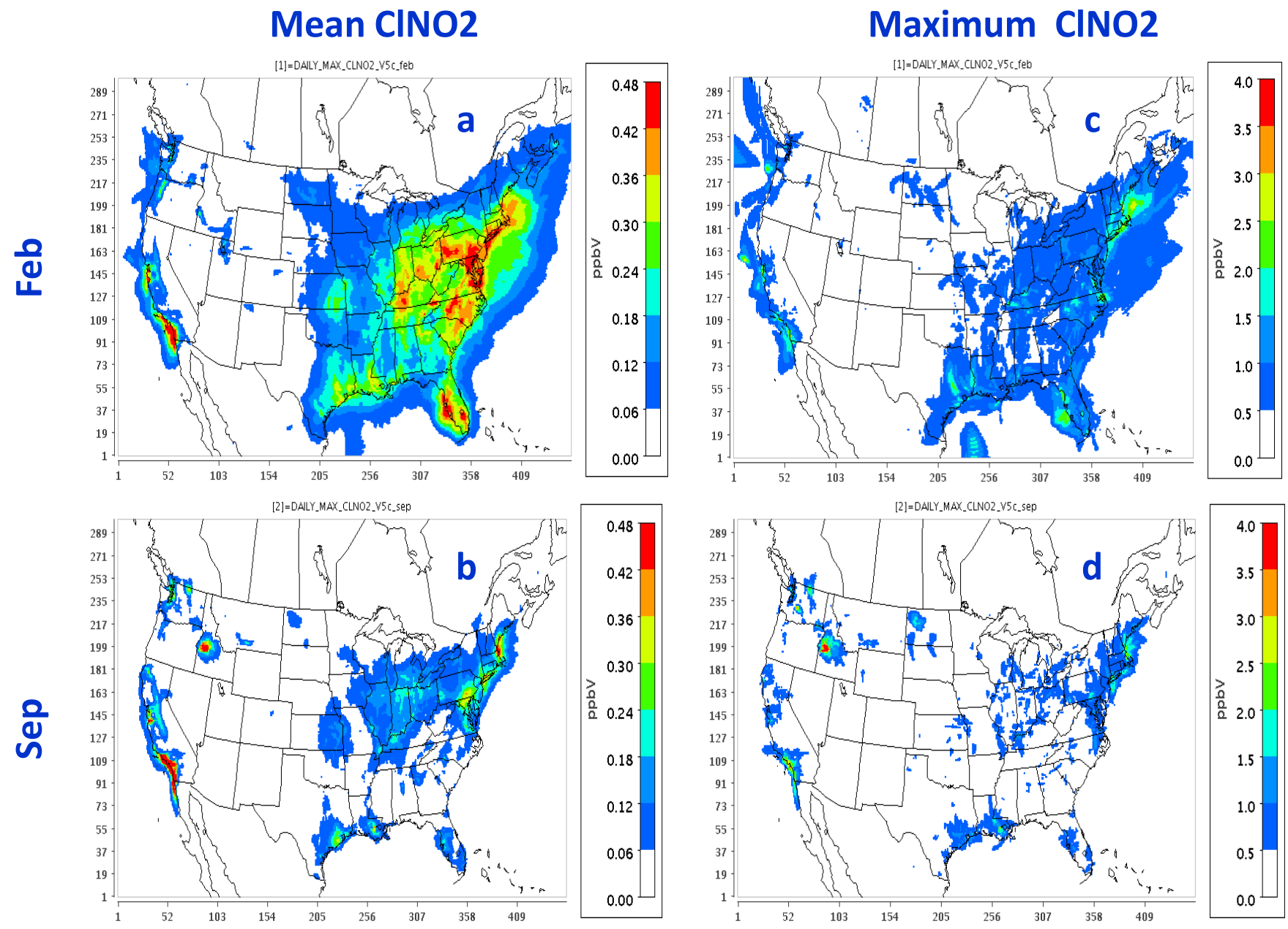

Fig. 3. Predicted mean of daily maximum $\mathrm{ClNO}_{2}$ in (a) February, (b) September. Predicted hourly maximum $\mathrm{ClNO}_{2}$ in (c) February, (d) September. It should be noted that the largest hourly value for each grid-cell in the entire month is shown in (c) and (d).

Table 4. A comparison of predicted nitryl chloride with observed data.

\begin{tabular}{lllccc}
\hline $\begin{array}{l}\text { Measurement } \\
\text { location }\end{array}$ & $\begin{array}{l}\text { Measurement time } \\
\text { period }\end{array}$ & References & $\begin{array}{c}\text { Peak measurement } \\
\text { (pptv) }\end{array}$ & $\begin{array}{c}\text { Peak prediction in } \\
\text { February (pptv) }\end{array}$ & $\begin{array}{c}\text { Peak prediction in } \\
\text { September (pptv) }\end{array}$ \\
\hline Houston, Texas & $8 / 30-9 / 8,2006$ & Osthoff et al. (2008) & 1200 & 2000 & 1500 \\
Boulder, Colorado & $2 / 11-2 / 25,2009$ & Thornton et al. (2010) & 450 & 300 & 200 \\
Calgary, Alberta & $4 / 16-4 / 21,2010$ & Mielke et al. (2011) & 250 & 500 & 300 \\
Los Angeles, California & $5 / 15-6 / 15,2010$ & Mielke et al. (2010) & 2550 & 2700 & 4000 \\
\hline
\end{tabular}

et al. (2010) reported a peak value of 450 pptv in Boulder, Colorado in February 2009. The predicted peak value in Boulder was 300 pptv in February and 200 pptv in September. Mielke et al. (2011) reported a peak $\mathrm{ClNO}_{2}$ value of 250 pptv in Calgary, Canada in April 2010. The predicted peak value in Calgary reached 500 pptv in February and 300 pptv in September. Mielke et al. (2010) reported a peak value of 2550 pptv in Los Angeles, California in June 2010. Predicted peak value in Los Angeles reached 2700 pptv in February and 4000 pptv in September. Predicted levels are similar to the observed values reported in the literature. It should be noted that measured and predicted values cannot be directly compared for several reasons. First, predicted values are hourly averaged while measurements are conducted at a much finer temporal resolution. Moreover, simulation and observed time periods are different (except for Houston, TX). Nevertheless, the model tends to slightly over-predict $\mathrm{CINO}_{2}$ compared to the observed data. Such over-predictions can be caused by several reasons including over-estimation of $\gamma_{\mathrm{N}_{2}} \mathrm{O}_{5}$ as indicated earlier. Based on these comparisons, the model 

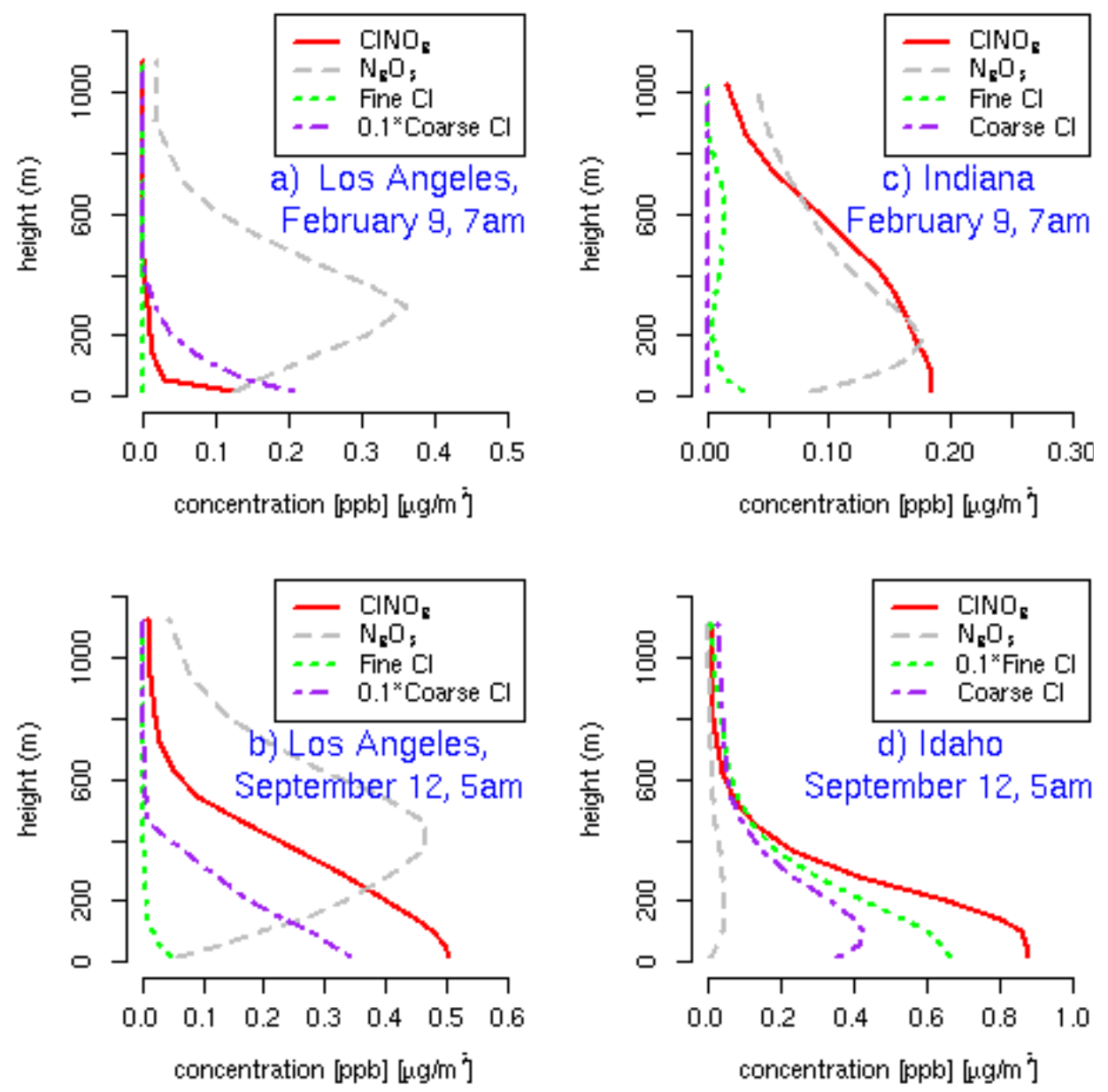

Fig. 4. Vertical profiles of $\mathrm{ClNO}_{2}, \mathrm{~N}_{2} \mathrm{O}_{5}$, coarse $\mathrm{Cl}$, and fine $\mathrm{Cl}$ for (a) Los Angeles on 9 February 2006 at 7 a.m. (note that coarse $\mathrm{Cl}$ is divided by 10 to fit on scale), (b) Los Angeles on 12 September 2006 (5 a.m.) (note that coarse $\mathrm{Cl}$ is divided by 10 to fit on scale), (c) Indiana on 9 February 2006 at 7 a.m., (d) Idaho on 12 September 2006 at 5 a.m. (note that fine $\mathrm{Cl}$ is divided by 10 to fit on scale). Units of $\mathrm{ClNO}_{2}$ and $\mathrm{N}_{2} \mathrm{O}_{5}$ are in [ppb] while units of fine and coarse $\mathrm{Cl}$ are in $\left[\mu \mathrm{g} \mathrm{m}^{-3}\right]$.

parameterizations of yield and $\gamma_{\mathrm{N}_{2}} \mathrm{O}_{5}$ along with our emissions of $\mathrm{NO}_{\mathrm{x}}$ and gas and particle-phase chlorine compounds appear to do a reasonable job of replicating the chemistry that leads to $\mathrm{ClNO}_{2}$ production.

\subsection{Impact of the heterogeneous $\mathrm{ClNO}_{2}$ production on selected gaseous and particle species}

\subsubsection{Monthly mean concentrations}

Monthly mean $\mathrm{O}_{3}$ levels in the base simulation and changes due to the heterogeneous production are presented in Fig. 5. Monthly mean $\mathrm{O}_{3}$ levels between 30 and 50 ppbv in February and between 40 and $65 \mathrm{ppbv}$ in September were modeled over most areas in the United States. The heterogeneous $\mathrm{ClNO}_{2}$ production enhanced monthly mean $\mathrm{O}_{3}$ by a maximum of 1.3 ppbv in February and 1.4 ppbv in September. On a percentage basis, the $\mathrm{O}_{3}$ enhancement reached up to $4 \%$ and $3 \%$ in February and September, respectively. Enhance- ments in February occurred over a larger geographic area than those in September. Predictions of $\mathrm{ClNO}_{2}$ occurred over a wider area in February; consequently enhancements also occurred over a larger geographic area. Although not shown here, the heterogeneous $\mathrm{ClNO}_{2}$ production enhanced mean $\mathrm{HO}_{2}$ and $\mathrm{RO}_{2}$ by a few percent. These radicals increased primarily due to the oxidation of VOCs by $\mathrm{Cl}$ which is produced via the photolysis of $\mathrm{ClNO}_{2}$. Enhancements of $\mathrm{O}_{3}$ in the heterogeneous $\mathrm{ClNO}_{2}$ formation simulation were due both to the increased $\mathrm{HO}_{2}$ and $\mathrm{RO}_{2}$ radicals and due to the increased availability of $\mathrm{NO}_{2}$.

Monthly mean total nitrate $\left(\mathrm{TNO}_{3}\right)$ levels in the base simulation and changes due to the heterogeneous production are presented in Fig. 6. Here we define $\mathrm{TNO}_{3}$ as the sum of gas-phase $\mathrm{HNO}_{3}$ and fine and coarse particle nitrate. Mean $\mathrm{TNO}_{3}$ levels of more than $4.0 \mu \mathrm{g} \mathrm{m}^{-3}$ are predicted over most of the eastern United States and southern California in February and over parts of Midwest, southern United States, and southern California in September. The activation 

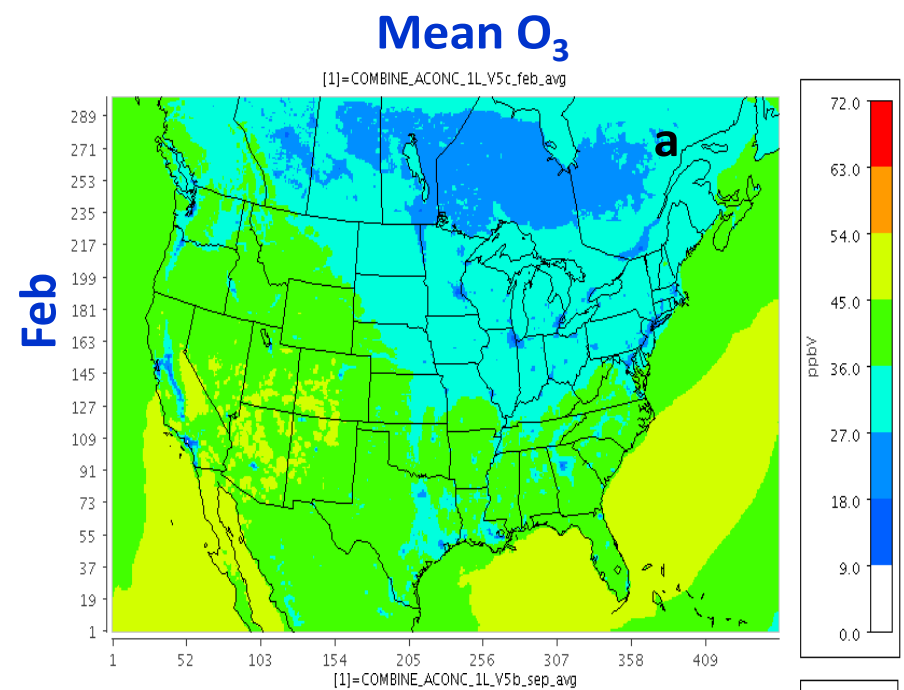

Changes in mean $\mathrm{O}_{3}$
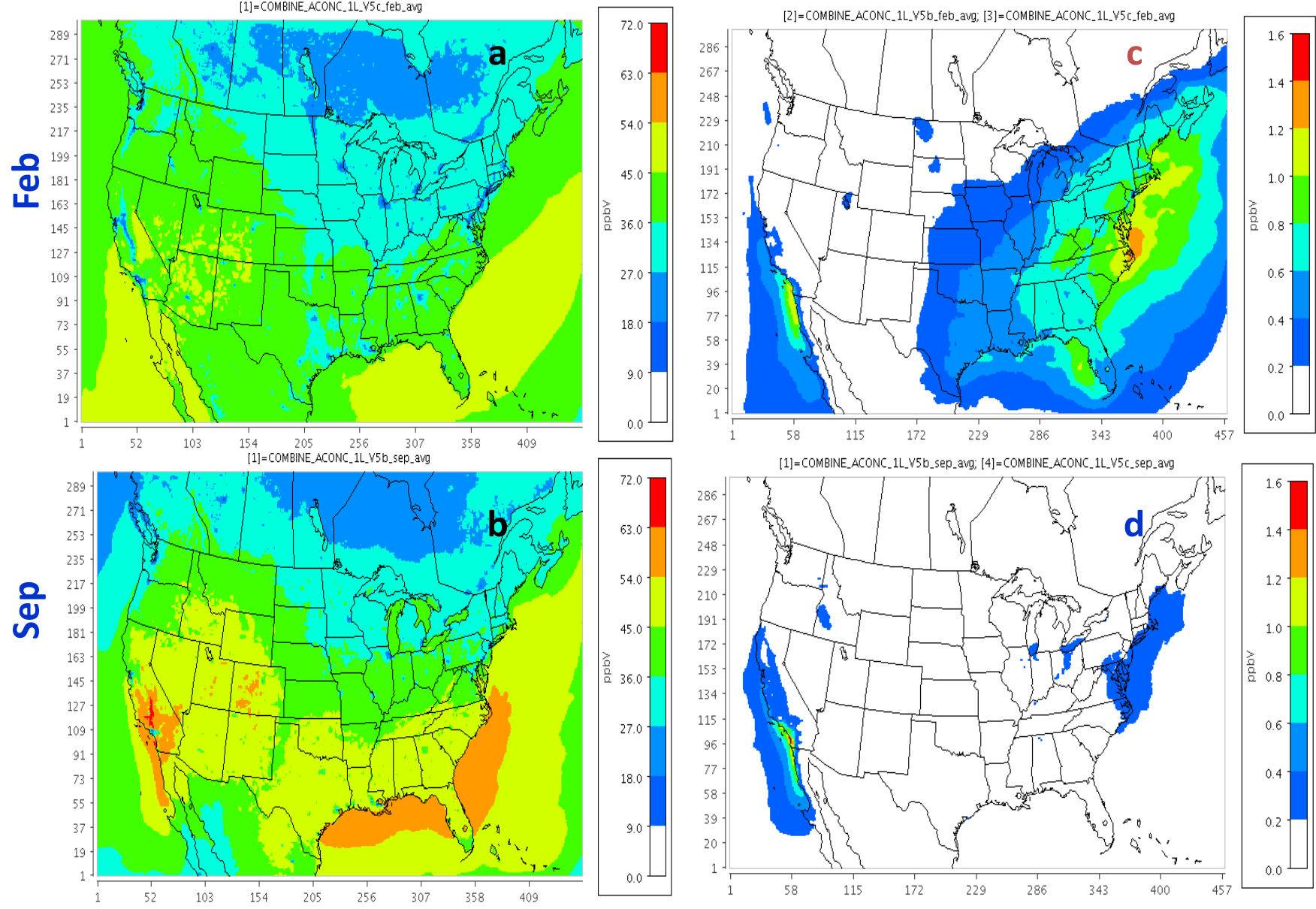

Fig. 5. Impact of the heterogeneous $\mathrm{ClNO}_{2}$ production on $\mathrm{O}_{3}$ : (a) mean $\mathrm{O}_{3}$ without the heterogeneous production in February, (b) mean $\mathrm{O}_{3}$ without the heterogeneous production in September, (c) increases in monthly mean $\mathrm{O}_{3}$ due to the heterogeneous production in February, (d) increases in monthly mean $\mathrm{O}_{3}$ due to the heterogeneous production in September.

of the heterogeneous $\mathrm{ClNO}_{2}$ pathway reduced the production of $\mathrm{HNO}_{3}$ via the $\mathrm{N}_{2} \mathrm{O}_{5}$ hydrolysis which then decreased $\mathrm{TNO}_{3}$ both in February and September. The mean decreases in February were up to $0.8 \mu \mathrm{g} \mathrm{m}^{-3}$ while the decrease in September reached $2.0 \mathrm{\mu g} \mathrm{m}^{-3}$. On a percentage basis, the reductions were up to $11 \%$ and $21 \%$ in February and September, respectively. Both high nitrate concentrations and large nitrate decreases covered a broader area in February than in September.

The heterogeneous $\mathrm{ClNO}_{2}$ production also enhanced sulfate by $<0.1 \mu \mathrm{g} \mathrm{m}^{-3}$, decreased ammonium by $<0.3 \mu \mathrm{g} \mathrm{m}^{-3}$, and increased anthropogenic and biogenic secondary organic aerosols by $<0.003 \mu \mathrm{g} \mathrm{m}^{-3}$. These changes are due to shifts in the radical budget and $\mathrm{NO}_{\mathrm{x}}$ availability and are not discussed further in this paper.

To evaluate the sensitivity of the model results to particulate chloride concentrations, two additional simulations were conducted with increased chlorine emissions [3.0 $\times$ (anthropogenic particulate chloride, $\mathrm{Cl}_{2}, \mathrm{HCl}$ ) emissions used for the previous two simulations] for 10 days in February. One simulation was conducted without the heterogeneous production of $\mathrm{ClNO}_{2}$ and the other simulation was conducted with the heterogeneous production of $\mathrm{ClNO}_{2}$. The additional chlorine emissions further increased $\mathrm{ClNO}_{2}$ and $\mathrm{O}_{3}$ and further decreased $\mathrm{TNO}_{3}$. Heterogeneous $\mathrm{ClNO}_{2}$ chemistry combined with the augmented chlorine emissions increased mean daily maximum $\mathrm{ClNO}_{2}$ by up to $1.05 \mathrm{ppb}$ compared to the value of $0.88 \mathrm{ppbv}$ with the normal emissions. Similarly, heterogeneous $\mathrm{ClNO}_{2}$ chemistry combined with the augmented chlorine emissions increased mean $\mathrm{O}_{3}$ by up to $2.1 \mathrm{ppb}$ compared to the value of $1.2 \mathrm{ppbv}$ with the normal emissions. Mean $\mathrm{O}_{3}$ in the northeast United States increased by $1.0-2.0 \mathrm{ppb}$ with the augmented chlorine emissions, while mean $\mathrm{O}_{3}$ increased only by $0.6-1.0 \mathrm{ppbv}$ with the base case emissions. The augmented chlorine emissions decreased mean $\mathrm{TNO}_{3}$ by up to $1.2 \mu \mathrm{g} \mathrm{m}^{-3}$ compared to the value of $0.9 \mathrm{\mu g} \mathrm{m}^{-3}$ with the normal emissions. In the Midwest, this decrease in mean $\mathrm{TNO}_{3}$ was $0.4-0.6 \mu \mathrm{g} \mathrm{m}^{-3}$ 

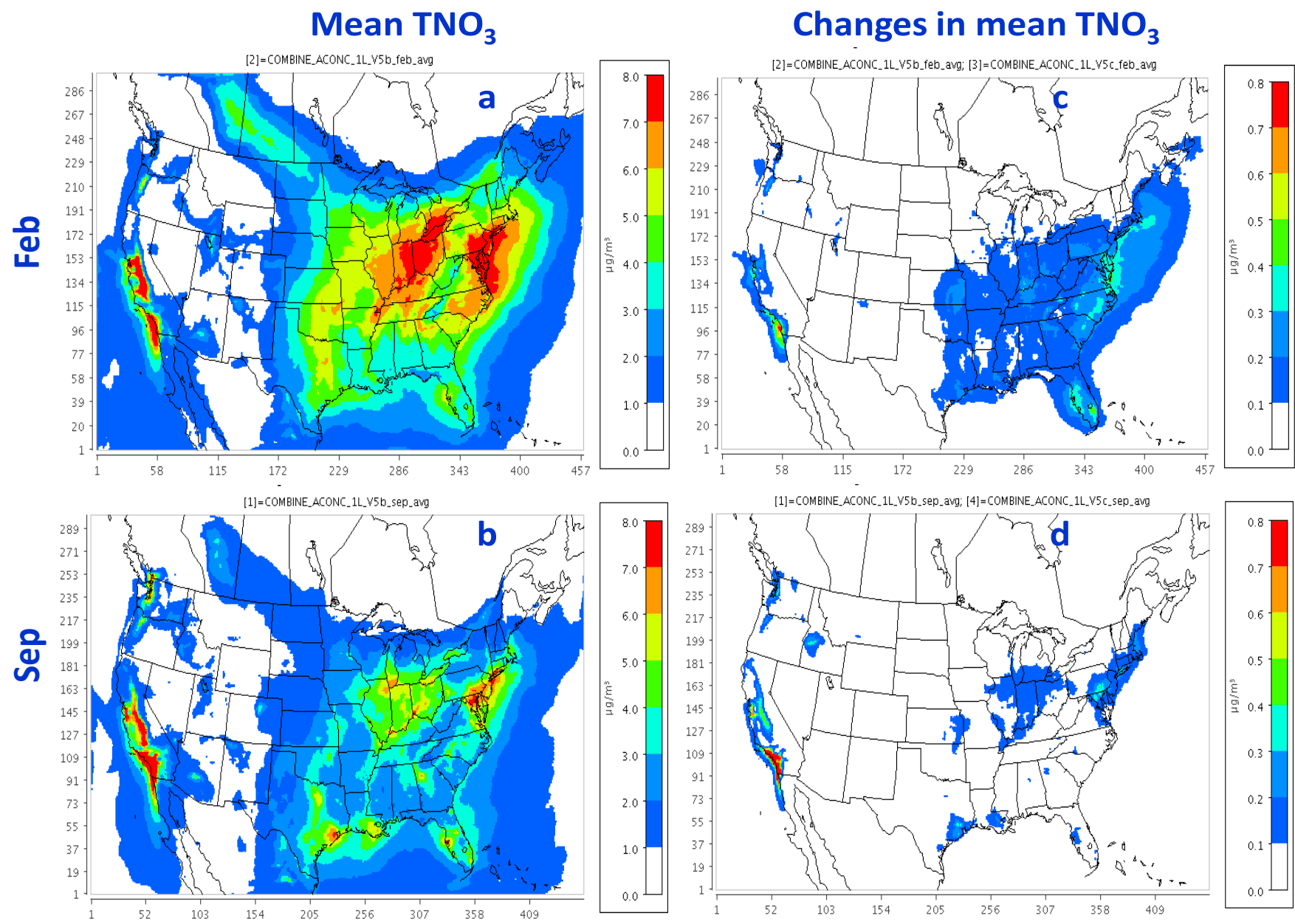

Fig. 6. Impact of the heterogeneous $\mathrm{ClNO}_{2}$ production on $\mathrm{TNO}_{3}\left(\mathrm{HNO}_{3}+\right.$ aerosol nitrate): (a) mean $\mathrm{TNO}_{3}$ without the heterogeneous production in February, (b) mean $\mathrm{TNO}_{3}$ without the heterogeneous production in September, (c) decreases in mean $\mathrm{TNO}_{3}$ due to the heterogeneous production in February, (d) decreases in mean $\mathrm{TNO}_{3}$ due to the heterogeneous production in September.

compared to a value of $0.1-0.3 \mu \mathrm{g} \mathrm{m}^{-3}$ with normal emissions. The impacts on $\mathrm{ClNO}_{2}, \mathrm{O}_{3}$ and $\mathrm{TNO}_{3}$ were more pronounced with the enhanced emissions. These results suggest that the heterogeneous production of $\mathrm{ClNO}_{2}$ can further increase $\mathrm{O}_{3}$ and lower $\mathrm{TNO}_{3}$ predictions if elevated chlorides are present in the atmosphere.

\subsubsection{Day-to-day variation}

Several areas were identified as having high modeled $\mathrm{ClNO}_{2}$ concentrations in Sect. 3.3. Here we examine the temporallyresolved changes in $\mathrm{ClNO}_{2}, \mathrm{O}_{3}$, and $\mathrm{TNO}_{3}$ in those areas. Time series of the changes in $\mathrm{ClNO}_{2}, \mathrm{O}_{3}$, and $\mathrm{TNO}_{3}$ due to the heterogeneous production in Los Angeles, Indiana, and Idaho are shown Fig. 7. These values are averaged over each representative region and since $\mathrm{ClNO}_{2}$ formation chemistry can occur in localized areas, this analysis does not show the maximum impact of that chemistry. Figure 7 shows that $\mathrm{ClNO}_{2}$ concentrations increase every night in Los Angeles in both February and September. Predicted increases in $\mathrm{ClNO}_{2}$ in February are lower than those in September in Los Angeles. Nightly concentrations averaged over the Los Angeles area range $0.15 \mathrm{ppbv}$ to above $1.0 \mathrm{ppbv}$. These fairly routine $\mathrm{ClNO}_{2}$ episodes are due to the constant source of particulate chloride from sea-salt and $\mathrm{NO}_{\mathrm{x}}$ from mobile sources. Ozone enhancements and $\mathrm{TNO}_{3}$ decrease due to the $\mathrm{ClNO}_{2}$ chemistry are predicted daily in Los Angeles and range from 0.3 to $3 \mathrm{ppb}$ for $\mathrm{O}_{3}$ and from 0.1 to $4.0 \mu \mathrm{g} \mathrm{m}^{-3}$ for $\mathrm{TNO}_{3}$. Anthropogenic particulate chloride emissions are responsible for the chlorine available for heterogeneous production in Indiana and enhanced $\mathrm{ClNO}_{2}$ and $\mathrm{O}_{3}$, and decreased $\mathrm{TNO}_{3}$ on most days in February. Chloride and $\mathrm{NO}_{\mathrm{x}}$ emissions from a large wildfire in Idaho activated the heterogeneous production and increased $\mathrm{ClNO}_{2}$ and $\mathrm{O}_{3}$ up to $1 \mathrm{ppbv}$ and $2.5 \mathrm{ppbv}$, respectively, and decreased $\mathrm{TNO}_{3}$ by up to $2.5 \mu \mathrm{g} \mathrm{m}^{-3}$ over a large portion of Idaho. The wildfire was active only during the first part in September and consequently the heterogeneous production during the second part in September is negligible. Thus, the heterogeneous $\mathrm{ClNO}_{2}$ production is active on most 

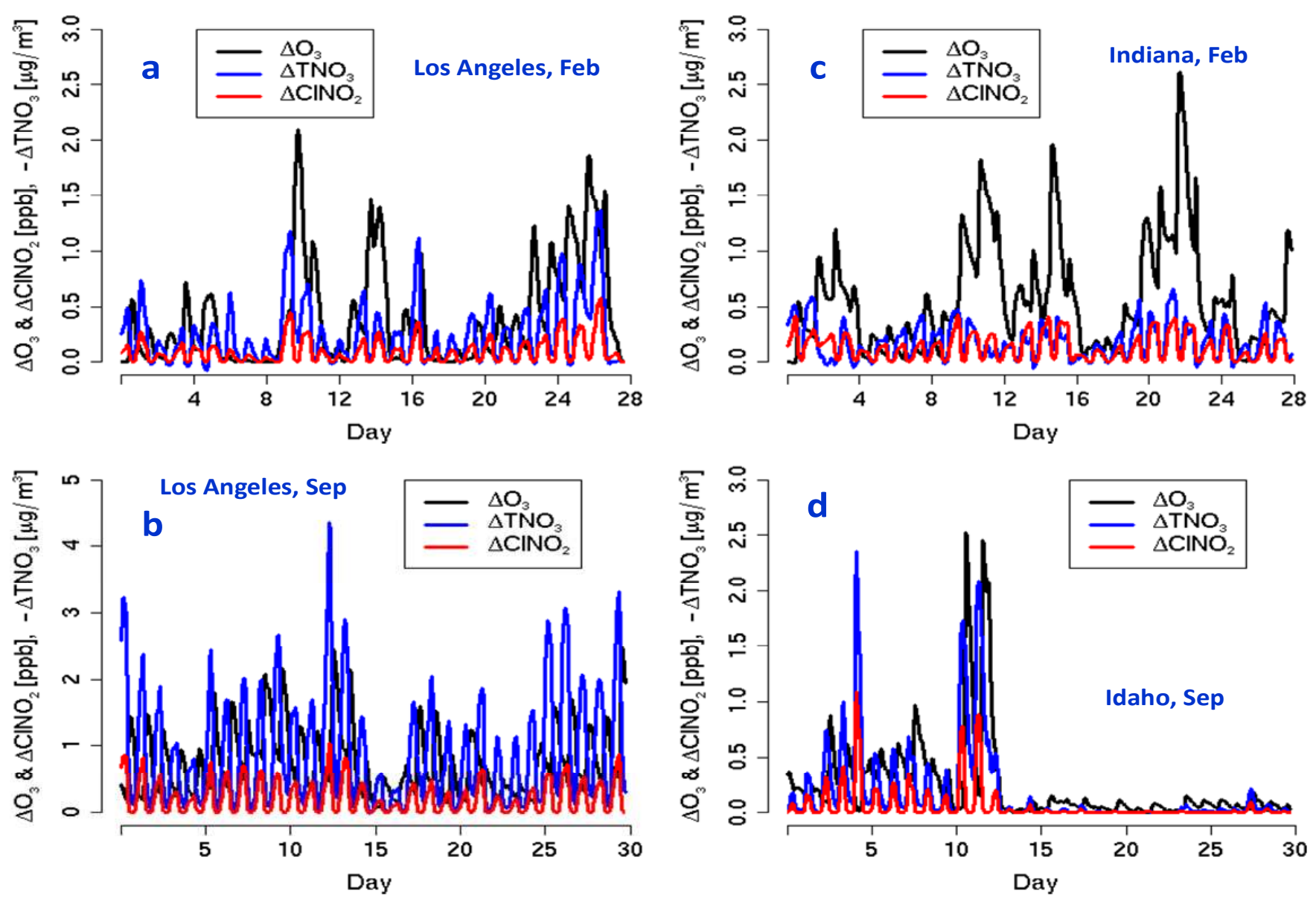

Fig. 7. Time series of the absolute value of changes in $\mathrm{ClNO}_{2}, \mathrm{O}_{3}$, and $-\mathrm{TNO}_{3}$ at (a) Los Angeles in February, (b) Los Angeles in September, (c) Indiana in February, (d) Idaho in September. All $\Delta$ values are positive for $\mathrm{O}_{3}$ and $\mathrm{ClNO}_{2}$ and negative for $\mathrm{TNO}_{3}$.

days in some areas while it is activated by sporadic events such as wildfires or large industrial emissions in other areas.

\subsubsection{Diurnal variation of the impact}

Figure 8 shows average diurnal changes in $\mathrm{ClNO}_{2}, \mathrm{O}_{3}, \mathrm{TNO}_{3}$ in Los Angeles, Indiana, and northeastern United States due to the heterogeneous production of $\mathrm{ClNO}_{2}$. Again, these changes are averaged over each representative area. $\mathrm{ClNO}_{2}$ increased during the course of the night, reached peak levels in the early morning and then decreased due to the photolysis and dropped to its lowest level in the afternoon. The peak $\mathrm{ClNO}_{2}$ levels in February occurred somewhat later in the morning than those in September due to the lower photolysis rate and late sun rise. The modeled diurnal pattern of $\mathrm{CINO}_{2}$ agrees well with observed profile reported by Thornton et al. (2010). The $\mathrm{O}_{3}$ enhancement started in the morning and reached a peak value in the afternoon and then decreased. The time of peak $\mathrm{O}_{3}$ increase varied by season; $\mathrm{O}_{3}$ enhancements reached their peak around noon in September and later in the afternoon in February. So even though $\mathrm{ClNO}_{2}$ photolysis released $\mathrm{Cl}$ radicals and $\mathrm{NO}_{2}$ in the first several hours after sunrise, these model simulations predict that its effect on $\mathrm{O}_{3}$ continues well into the day meaning that $\mathrm{ClNO}_{2}$ production will have a noticeable impact of 8-h daily maximum $\mathrm{O}_{3}$, the regulatory metric used to identify areas in violation with national air quality standards in the US. The decrease in $\mathrm{TNO}_{3}$ followed the same diurnal pattern as the changes in $\mathrm{ClNO}_{2}$ since the decrease of $\mathrm{HNO}_{3}$ is a direct result of the heterogeneous $\mathrm{N}_{2} \mathrm{O}_{5}$ chemistry following the pathway of $\mathrm{ClNO}_{2}$ formation (R10) rather than $\mathrm{HNO}_{3}$ production (R9). Similar diurnal pattern of the changes in $\mathrm{ClNO}_{2}, \mathrm{O}_{3}, \mathrm{TNO}_{3}$ were observed in other areas.

\subsubsection{Impact on daily maximum $8-\mathrm{h} \mathrm{O}_{3}$}

Predicted mean 8-h daily maximum $\mathrm{O}_{3}$ in the base simulation and enhancements due to the heterogeneous production are presented in Fig. 9. Predicted mean 8-h daily maximum $\mathrm{O}_{3}$ without the heterogeneous production are greater than 46 ppbv in most of the United States in September while predicted values are lower than 46 ppbv in February. The heterogeneous production enhanced the monthly mean 8-h daily maximum $\mathrm{O}_{3}$ by up to 1.7 ppbv in February and 1.9 ppbv in 

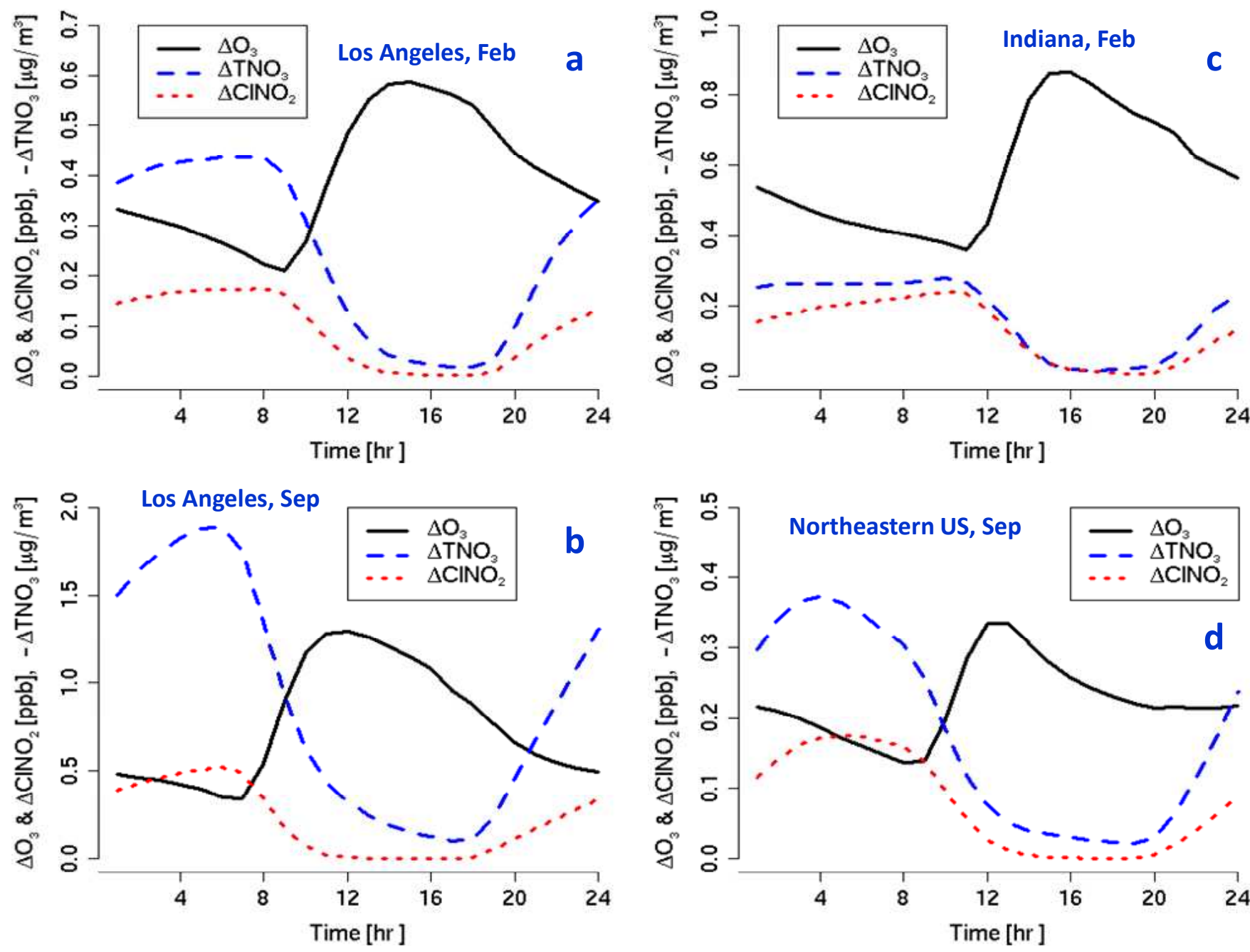

Fig. 8. Average diurnal absolute value of changes in $\mathrm{ClNO}_{2}, \mathrm{O}_{3}$, and $-\mathrm{TNO}_{3}$ at (a) Los Angeles in February, (b) Los Angeles in September, (c) Indiana in February, (d) Northeastern United States in September. All $\Delta$ values are positive for $\mathrm{O}_{3}$ and $\mathrm{ClNO}_{2}$ and negative for $\mathrm{TNO}_{3}$.

September. On a percentage basis, the enhancement reached up to $4 \%$ and $3 \%$ in February and September, respectively. The largest monthly mean impact occurred in Los Angeles both in February and September. Predicted maximum changes in 8-h $\mathrm{O}_{3}$ are also shown in Fig. 9 for February and September. The largest enhancement in daily maximum 8 -h $\mathrm{O}_{3}$ in any grid-cell was $13.3 \mathrm{ppb}$ in February and $6.6 \mathrm{ppbv}$ in September. On a percentage basis, the largest enhancement in daily maximum 8-h $\mathrm{O}_{3}$ in any grid-cell was $43 \%$ in February and $10 \%$ in September. Although mean enhancements in maximum 8-h $\mathrm{O}_{3}$ are modest, impacts on specific days can be quite large. The addition of $\mathrm{ClNO}_{2}$ heterogeneous chemistry also increases the number of days any grid-cells exceed the National Ambient Air Quality Standards of $75 \mathrm{ppbv}$ in Los Angeles and other areas (the maximum increase in any grid cell was 7 additional days in September).

\subsection{Impact on the composition of total reactive nitrogen $\left(\mathrm{NO}_{\mathrm{y}}\right)$}

The monthly mean of daily maximum $\mathrm{ClNO}_{2}: \mathrm{NO}_{\mathrm{y}}$ ratios without the heterogeneous $\mathrm{ClNO}_{2}$ production were negligible $(<0.005)$. Heterogeneous $\mathrm{ClNO}_{2}$ production increased monthly mean of daily maximum $\mathrm{ClNO}_{2}: \mathrm{NO}_{\mathrm{y}}$ ratios up to 0.06 in February as well as in September. Higher $\mathrm{ClNO}_{2}: \mathrm{NO}_{\mathrm{y}}$ ratios occurred over a larger geographic area in February than those in September. As $\mathrm{TNO}_{3}$ concentrations decreased with the heterogeneous $\mathrm{ClNO}_{2}$ production, so did their contribution to $\mathrm{NO}_{\mathrm{y}}$. While the monthly mean $\mathrm{ClNO}_{2}: \mathrm{NO}_{\mathrm{y}}$ ratios were small, the maximum hourly $\mathrm{ClNO}_{2}: \mathrm{NO}_{\mathrm{y}}$ ratios are much greater and reached 0.34 in February and 0.17 in September. The contribution of $\mathrm{ClNO}_{2}$ to $\mathrm{NO}_{\mathrm{y}}$ was greater in February than in September; thus, the ratio was also generally higher in February. Our predicted maximum hourly $\mathrm{ClNO}_{2}: \mathrm{NO}_{\mathrm{y}}$ ratios agree well with the 


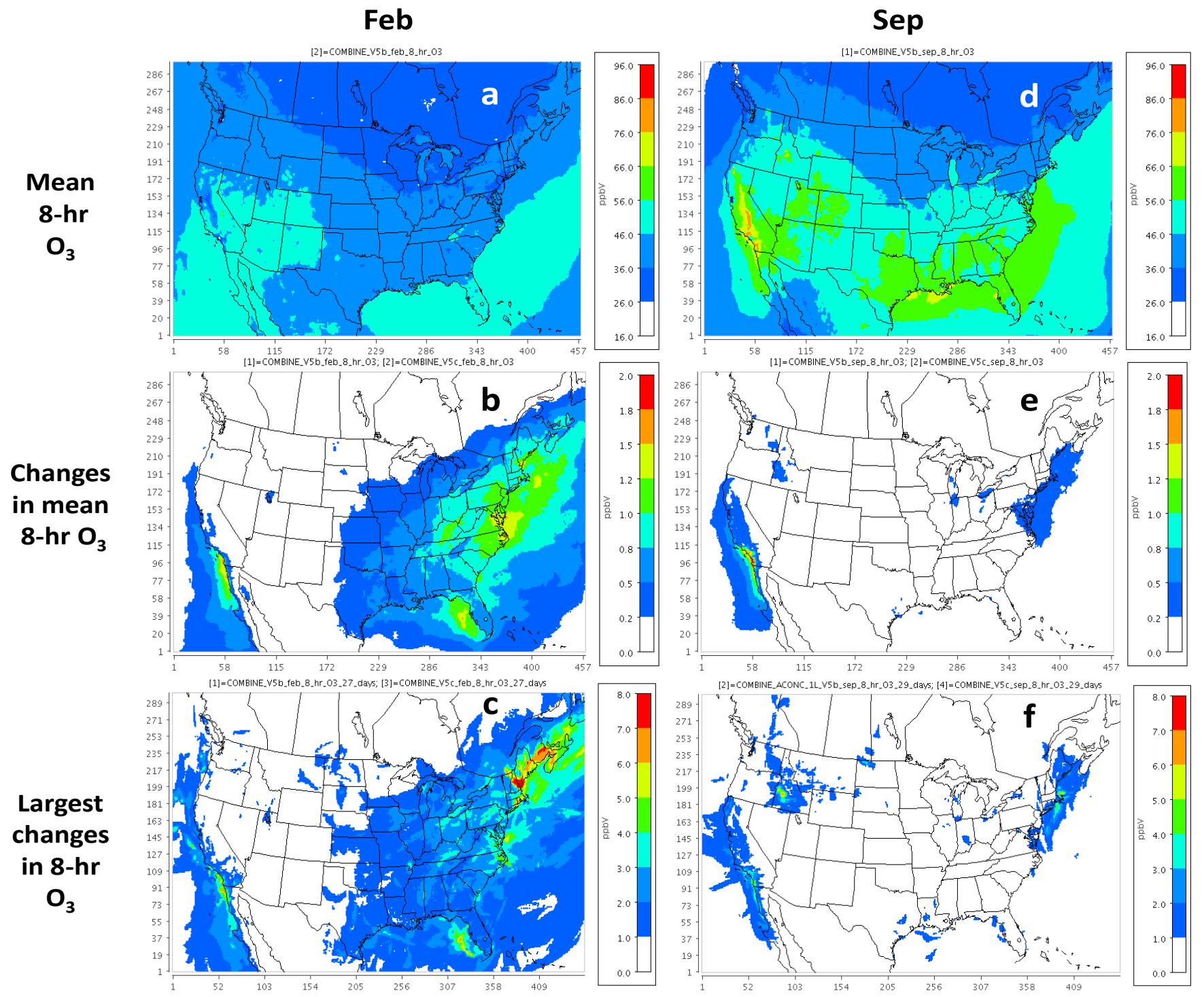

Fig. 9. (a) Predicted monthly average of 8-h daily maximum $\mathrm{O}_{3}$ in February, (b) changes in monthly average of 8-h daily maximum $\mathrm{O}_{3}$ due to the heterogeneous production in February, (c) the largest changes in daily maximum 8-h $\mathrm{O}_{3}$ due to the heterogeneous production in February, (d) predicted monthly average of 8-h daily maximum $\mathrm{O}_{3}$ in September, (e) changes in monthly average of 8-h daily maximum $\mathrm{O}_{3}$ due to the heterogeneous production in September, (f) the largest changes in daily maximum $8-\mathrm{h} \mathrm{O}_{3}$ due to the heterogeneous production in September.

results of Thornton et al. (2010) who suggested up to $22 \%$ of $\mathrm{NO}_{\mathrm{x}}$ may be cycled through $\mathrm{ClNO}_{2}$.

\subsection{Impact of $\gamma_{\mathrm{N}_{2} \mathrm{O}_{5}}$ parameterization on model predictions}

The presence of particulate chloride can increase $\gamma_{\mathrm{N}_{2} \mathrm{O}_{5}}$ as described by Bertram and Thornton (2009). However particulate chloride is not explicitly accounted for in the $\gamma_{\mathrm{N}_{2}} \mathrm{O}_{5}$ which is described by Davis et al. (2008) and used in this work and in the current version of CMAQ. The Davis et al. (2008) parameterization accounts for PM concentrations of sulfate, nitrate, ammonium, and water, phase of the
PM (ice versus aqueous) and temperature. However, it does not account for the effect of particulate chloride on $\gamma \mathrm{N}_{2} \mathrm{O}_{5}$. Bertram and Thornton (2009) account for the effect of particulate chloride on $\gamma_{\mathrm{N}_{2}} \mathrm{O}_{5}$ but neglect the effects of temperature and PM phase. Both parameterizations account for decreasing $\gamma_{\mathrm{N}_{2} \mathrm{O}_{5}}$ with increased nitrate concentrations, but the Bertram and Thornton (2009) formulation is based on a mechanistic description of the nitrate inhibition effect while Davis et al. (2008) uses a linear relationship. To evaluate the sensitivity of the model results to $\gamma_{\mathrm{N}_{2}} \mathrm{O}_{5}$, two additional simulations were completed for a 10-day period in each month. The first simulation employed $\gamma_{\mathrm{N}_{2} \mathrm{O}_{5}}$ (Eq. 4) of Bertram and 
Thornton (2009) on both fine and coarse particles and used $Y=0$. The second simulation employed $\gamma_{\mathrm{N}_{2} \mathrm{O}_{5}}$ of Bertram and Thornton (2009) on both fine and coarse particles with $Y$ calculated using Eq. (3). The differences in results obtained with the two simulations are compared to those obtained with the previous two simulations employing $\gamma_{\mathrm{N}_{2} \mathrm{O}_{5}}$ of Davis et al. (2008) on fine particles and $\gamma_{\mathrm{N}_{2} \mathrm{O}_{5}}$ of Bertram and Thornton (2009) on coarse particles. While enhancements in hourly $\mathrm{O}_{3}$ obtained with the two $\gamma_{\mathrm{N}_{2} \mathrm{O}_{5}}$ varied occasionally by $1-2 \mathrm{ppbv}$, the enhancements in mean 8 -h $\mathrm{O}_{3}$ obtained with the two $\gamma_{\mathrm{N}_{2} \mathrm{O}_{5}}$ formulations did not differ significantly $(<0.2 \mathrm{ppb})$. The decreases in mean $\mathrm{TNO}_{3}$ obtained with the $\gamma_{\mathrm{N}_{2} \mathrm{O}_{5}}$ of Bertram and Thornton (2009) on both fine and coarse particles were greater than those obtained with the modeling simulations described in the main portion of this paper (Figs. S6 and S7). Thus, the use of $\gamma_{\mathrm{N}_{2} \mathrm{O}_{5}}$ of Bertram and Thornton (2009) on both fine and coarse particles can further reduce $\mathrm{TNO}_{3}$ without further enhancement of $\mathrm{O}_{3}$.

\section{Summary}

Heterogeneous $\mathrm{ClNO}_{2}$ chemistry is successfully implemented into the CMAQ model along with a comprehensive inventory of chlorine and reactive nitrogen emissions. While the homogeneous production of $\mathrm{ClNO}_{2}$ is negligible, the heterogeneous production can enhance $\mathrm{ClNO}_{2}$ in coastal areas, the eastern half of the United States, and Idaho. Sea-salt derived particulate chloride enhances $\mathrm{ClNO}_{2}$ in coastal areas while anthropogenic particulate chloride enhances $\mathrm{ClNO}_{2}$ in the eastern half of the United States and chloride from forest fires enhances $\mathrm{ClNO}_{2}$ in wildfire plumes. Mean of daily maximum $\mathrm{ClNO}_{2}$ levels increase by up to $1.0 \mathrm{ppbv}$ in February and $1.5 \mathrm{ppbv}$ in September though the maximum hourly values are greater.

Predicted $\mathrm{ClNO}_{2}$ enhances monthly mean 8-h $\mathrm{O}_{3}$ modestly but enhances 8-h daily maximum $\mathrm{O}_{3}$ concentrations quite substantially in some episodes. It can, however, decrease mean $\mathrm{TNO}_{3}$ by larger margins and improve model performance statistics. Predicted $\mathrm{ClNO}_{2}$ reaches its peak level in the early morning while the $\mathrm{O}_{3}$ enhancement starts in the morning and reaches a peak value in the afternoon. The impact of the heterogeneous production occurs over a larger geographical area in February. The heterogeneous production of $\mathrm{ClNO}_{2}$ changes the composition of $\mathrm{NO}_{\mathrm{y}}$; predicted $\mathrm{ClNO}_{2}$ can account for up to $6 \%$ of the monthly mean $\mathrm{NO}_{\mathrm{y}}$ but up to $34 \%$ of $\mathrm{NO}_{\mathrm{y}}$ in some localized episodes.

The results of this study compare favorably to the findings of Simon et al. (2009) who reported that the heterogeneous $\mathrm{ClNO}_{2}$ production can increase daily maximum 8-h $\mathrm{O}_{3}$ in Houston by up to 1.5 ppbv. While the heterogeneous $\mathrm{ClNO}_{2}$ production in this study enhances monthly mean 8-h $\mathrm{O}_{3}$ by less than $0.2 \mathrm{ppbv}$ in Houston, it enhanced the daily maximum $8-\mathrm{h} \mathrm{O}_{3}$ on some days by levels similar to those reported by Simon et al. (2009). It should be noted that Si- mon et al. (2009) used 4-km grid resolution and this study uses $12-\mathrm{km}$ grid resolution. Since the modeling domain covers the entire United States, a larger grid resolution is used in this study. Emissions of $\mathrm{NO}_{\mathrm{x}}$ and VOCs used by Simon et al. (2009) are also different than those used in this study. One large improvement over the modeling formulation presented in that work is that this modeling uses generalized parameterizations for reactive uptake and $\mathrm{ClNO}_{2}$ yield while Simon et al. (2009) relied on local measurements to create fixed values for those variables. Our new model formulation has allowed for the investigation of the effects $\mathrm{ClNO}_{2}$ chemistry over the entire continental United States and over multiple seasons. Our predicted yields in Houston are lower than the fixed 0.75 value used by Simon et al. (2009). Results of this study suggest that the effect of $\mathrm{ClNO}_{2}$ production on air quality is more pronounced in several areas in the United States than it is in Houston. Field campaigns in those areas could validate the findings in this study.

\section{Supplementary material related to this article is available online at: http://www.atmos-chem-phys.net/12/ 6455/2012/acp-12-6455-2012-supplement.pdf.}

Edited by: C. H. Song

Disclaimer. Although this paper has been reviewed by EPA and approved for publication, it does not necessarily reflect EPA's policies or views.

\section{References}

Anttila, T., Kiendler-Scharr, A., Tillman, R., and Mentel, T. F.: On the reactive uptake of gaseous compounds by organic-coated aqueous aerosols: theoretical analysis and application to the heterogeneous hydrolysis of $\mathrm{N}_{2} \mathrm{O}_{5}$, J. Phys. Chem. A, 110, 1043510443, 2006.

Appel, K. W., Gilliland, A. B., Sarwar, G., and Gilliam, R. C.: Evaluation of the Community Multiscale Air Quality (CMAQ) model version 4.5: Sensitivities impacting model performance, Part IOzone, Atmos. Environ., 41, 9603-9615, 2007.

Atkinson, R., Baulch, D. L., Cox, R. A., Crowley, J. N., Hampson, R. F., Hynes, R. G., Jenkin, M. E., Kerr, J. A., Rossi, M. J., and Troe, J.: Summary of evaluated kinetic and photochemical data for atmospheric chemistry - IUPAC subcommittee on gas kinetic data evaluation for atmospheric chemistry, available at: http://www.iupac-kinetic.ch.cam.ac.uk/index.html, 2005.

Bertram, T. H. and Thornton, J. A.: Toward a general parameterization of $\mathrm{N}_{2} \mathrm{O}_{5}$ reactivity on aqueous particles: the competing effects of particle liquid water, nitrate and chloride, Atmos. Chem. Phys., 9, 8351-8363, doi:10.5194/acp-9-8351-2009, 2009.

Bey, I., Jacob, D. J., Yantosca, R. M., Logan, J. A., Field, B. D., Fiore, A. M., Li, Q., Liu, H. Y., Mickley, L. J., and Schultz, M. G.: Global modeling of tropospheric chemistry with assimilated meteorology: Model description and evaluation, J. Geophys. Res., 106, 23073-23096, 2001. 
Bhave, P. V. and Appel, K. W.: Evaluation of the CMAQ Model for Size-Resolved PM Composition, 8th Annual CMAS Models3 Users' Conference, 19-21 October, available at: http://www. cmascenter.org/conference/2009/agenda.cfm, UNC-Chapel Hill, NC, 2009.

Binkowski, F. S. and Roselle, S. J.: Community Multiscale Air Quality (CMAQ) model aerosol component, I: Model description, J. Geophys. Res., 108, 4183, doi:10.1029/2001JD001409, 2003.

Brown, S. S., Ryerson, T. B., Wollny, A. G., Brock, C. A., Peltier, R., Sullivan, A. P., Weber, R. J., Dube, W. P., Trainer, M., Meagher, J. F., Fehsenfeld, F. C., and Ravishankara, A. R.: Variability in nocturnal nitrogen oxide processing and its role in regional air quality, Science, 311, 67-70, 2006.

Bryukov, M. G., Dellinger, B., and Knyazev, V. D.: Kinetics of the gas-phase reaction of $\mathrm{OH}$ and HCL, J. Phys. Chem. A, 110, 936943, 2006.

Byun, D. and Schere, K. L.: Review of the governing equations, computational algorithms, and other components of the Models3 Community Multiscale Air Quality (CMAQ) modeling system, Appl. Mech. Rev., 59, 51-77, 2006.

Chang, S. and Allen, D. T.: Atmospheric chlorine chemistry in Southeast Texas: Impacts on ozone formation and control, Environ. Sci. Technol., 40, 251-262, 2006.

Chang, S., McDonald-Buller, E. C., Kimura, Y., Yarwood, G., Neece, J., Russel, M., Tanaka, P., and Allen, D.: Sensitivity of urban ozone formation to chlorine emission estimates, Atmos. Environ., 36, 4991-5003, 2002.

Chang, W. L., Bhave, P. V., Brown, S. T., Reimer, N., Stutz, J., and Dabdub, D.: Heterogeneous atmospheric chemistry, ambient measurements, and model calculations of $\mathrm{N}_{2} \mathrm{O}_{5}$ : a review, Aerosol Sci. Technol., 45, 665-695, 2011.

Davis, J. M., Bhave, P. V., and Foley, K. M.: Parameterization of $\mathrm{N}_{2} \mathrm{O}_{5}$ reaction probabilities on the surface of particles containing ammonium, sulfate, and nitrate, Atmos. Chem. Phys., 8, 52955311, doi:10.5194/acp-8-5295-2008, 2008.

Eder, B. and Yu, S.: A performance evaluation of the 2004 release of Models-3 CMAQ, Atmos. Environ., 40, 4811-4824, 2006.

Fan, J. and Zhang, R.: Atmospheric Oxidation mechanism of isoprene, Environ. Chem., 1, 140-149, 2004.

Finlayson-Pitts, B. J. and Pitts Jr., J. N.: Chemistry of the Upper Lower Atmosphere, Theory, Experiments and Applications, Academic Press, San Diego, 2000.

Finlayson-Pitts, B. J., Ezell, J. J., and Pitts Jr., J. N.: Formation of chemically active chlorine compounds by reactions of atmospheric $\mathrm{NaCl}$ particles with gaseous $\mathrm{N}_{2} \mathrm{O}_{5}$ and $\mathrm{ClONO}_{2}$, Nature, 337, 241-244, 1989.

Foley, K. M., Roselle, S. J., Appel, K. W., Bhave, P. V., Pleim, J. E., Otte, T. L., Mathur, R., Sarwar, G., Young, J. O., Gilliam, R. C., Nolte, C. G., Kelly, J. T., Gilliland, A. B., and Bash, J. O.: Incremental testing of the Community Multiscale Air Quality (CMAQ) modeling system version 4.7, Geosci. Model Dev., 3, 205-226, doi:10.5194/gmd-3-205-2010, 2010.

Fountoukis, C. and Nenes, A.: ISORROPIA II: a computationally efficient thermodynamic equilibrium model for $\mathrm{K}^{+}-\mathrm{Ca}^{2+}$. $\mathrm{Mg}^{2+}-\mathrm{NH}_{4}^{+}-\mathrm{Na}^{+}-\mathrm{SO}_{4}^{2-}-\mathrm{NO}_{3}^{-}-\mathrm{Cl}-\mathrm{H}_{2} \mathrm{O}$ aerosols, Atmos. Chem. Phys., 7, 4639-4659, doi:10.5194/acp-7-4639-2007, 2007.

Gery, M. W., Whitten, G. Z., Killus, J. P., and Dodge, M. C.: A photochemical kinetics mechanism for urban and regional scale computer modeling, J. Geophys. Res., 94, 12925-12956, 1989.

Houyoux, M. R., Vukovich, J. M., Coats Jr., C. J., Wheeler, N. M., and Kasibhatla, P. S.: Emission inventory development and processing for the seasonal model for regional air quality (SMRAQ) project, J. Geophys. Res., 105, 9079-9090, 2000.

Jacob, D. J.: Heterogeneous chemistry and tropospheric ozone, Atmos. Environ., 34, 2131-2159, 2000.

Kelly, J. T., Bhave, P. V., Nolte, C. G., Shankar, U., and Foley, K. M.: Simulating emission and chemical evolution of coarse seasalt particles in the Community Multiscale Air Quality (CMAQ) model, Geosci. Model Dev., 3, 257-273, doi:10.5194/gmd-3257-2010, 2010.

Knipping, E. M. and Dabdub, D.: Impact of chlorine emissions from sea-salt aerosol on coastal urban ozone, Environ. Sci. Technol., 37, 275-284, 2003.

Mielke, L. H., Flynn, J. H., Grossberg, N., Lefer, B. L., Veres, P. R., Roberts, J. M., Froyd, K. D., Cochran, A. K., and Osthoff, H. D.: Quantification and analysis of CalNex-LA 2010, American Geophysical Union, Fall Meeting 2010, San Francisco, California, available at: http://adsabs.harvard.edu/abs/2010AGUFM. A21C0118M, 2010.

Mielke, L. H., Furgeson, A., and Osthoff, H. D.: Observation of ClNO2 in a mid-continental urban environment, Environ. Sci. Technol., 45, 8889-8896, 2011.

Osthoff, H. D., Roberts, J. M., Ravishankara, A. R., Williams, E. J., Lerner, B. M., Sommariva, R., Bates, T. S., Coffman D., Quinn P. K., Dibb, J. E., Stark, H., Burkholder J. B., Talukdar, R. K., Meagher, J. M., Fehsenfeld, F. C., and Brown, S. S.: High levels of nitryl chloride in the polluted subtropical marine boundary layer, Nat. Geosci., 1, 324-328, 2008.

Oum, K. W., Lakin, M. J., DeHaan, D. O., Brauers, T., and Finlayson-Pitts, B. J.: Formation of molecular chlorine from the photolysis of ozone and aqueous sea-salt particles, Science, 279, 74-77, 1998.

Reff, A., Bhave, P. V., Simon, H., Pace, T. G., Pouliot, G. A., Mobley, J. D., and Houyoux, M.: Emissions inventory of PM2.5 trace elements across the United States, Environ. Sci.Technol., 43, 5790-5796, 2009.

Roberts, J. M., Osthoff, H. D., Brown, S. S., Ravishankara, A. R., Coffman, D., Quinn, P., and Bates, T.: Laboratory studies of products of N2O5 uptake on Cl- containing substrates, Geophys. Res. Lett., 36, L20808, doi:10.1029/2009GL040448, 2009.

Sarwar, G. and Bhave, P.: Modeling the effect of chlorine emissions on atmospheric ozone across the eastern United States, J. Appl. Meteorol. Clim., 46, 1009-1019, 2007.

Sarwar, G., Luecken, D., Yarwood, G., Whitten, G., and Carter, B.: Impact of an updated Carbon Bond mechanism on air quality using the Community Multiscale Air Quality modeling system: preliminary assessment, J. Appl. Meteorol. Clim., 47, 3-14, 2008.

Sarwar, G., Appel, K. W., Carlton, A. G., Mathur, R., Schere, K., Zhang, R., and Majeed, M. A.: Impact of a new condensed toluene mechanism on air quality model predictions in the US, Geosci. Model Dev., 4, 183-193, doi:10.5194/gmd-4-183-2011, 2011.

Schwede, D., Pouliot, G., and Pierce, T.: Changes to the biogenic emissions inventory system version 3 (BEIS3), 4th Annual CMAS Models-3 Users' Conference, 26-28 September 2005, UNC-Chapel Hill, NC, available at: http://www.cmascenter.org/ 
html/2005conference/abstracts/27.pdf, 2005.

Simon, H., Kimura, Y., McGaughey, G., Allen, D. T., Brown, S. S., Osthoff, H. D., Roberts, J. M., Byun, D., and Lee, D.: Modeling the impact of $\mathrm{ClNO} 2$ on ozone formation in the Houston area, J. Geophys. Res., 114, D00F03, doi:10.1029/2008JD010732, 2009.

Skamarock, W. C., Klemp, J. B., Dudhia, J., Grill, D. O., Barker, D. M., Duda, M. G, Huang, X.-Y., Wang, W., and Powers, J. G.: A description of the advanced research WRF version 3. NCAR Tech Note NCAR/TN 475 STR, 125 pp., available from UCAR Communications, P.O. Box 3000, Boulder, CO 80307, 2008.

Smith, J. D., DeSain, J. D., and Taatjes, C. A.: Infrared laser absorption measurements of $\mathrm{HCl}(v=1)$ production in reactions of $\mathrm{Cl}$ atoms with isobutane, methanol, acetaldehyde, and toluene at 295 K, Chem. Phys. Lett., 366, 417-425, 2002.

Tanaka, P., Allen, D. T., McDonald-Buller, E.C., Chang, S., Kimura, Y., Mullins, C. B., Yarwood,G., and Neece, J. D.: Development of a chlorine mechanism for use in the carbon bond IV chemistry model, J. Geophys. Res., 108, 4145, doi:10.1029/2002JD002432,2003a.

Tanaka, P. L., Riemer, D. D., Chang, S. H, Yarwood, G., McDonaldBuller, E. C., Apel, E. C.,Oralando, J. J., Silva, P. F., Jimenez, J. L., Canagaratna, M. R., Neece, J. D., Mullins, C. B., and Allen, D. T.: Direct evidence for chlorine-enhanced urban ozone formation in Houston, Texas, Atmos. Environ., 37, 1393-1400, 2003 b.
Thornton, J. A., Kercher, J. P., Riedel, T. P., Wagner, N. L., Cozic, J., Holloway, J. S., Dube, W. P, Wolfe, G. M., Quinn, P. K., Middlebrook, A. M., Alexander, B., and Brown, S. S.: A large atomic chlorine source inferred from mid-continental reactive nitrogen chemistry, Nature, 464, 271-274, 2010.

Wallington, T. J., Skewes, L. M., and Siegl, W. O.: Kinetics of the gas phase reaction of chlorine atoms with a series of alkenes, alkynes and aromatic species at $295 \mathrm{~K}$, J. Photochem. Photobiol. A, 45, 167-175, 1988.

Whitten, G. Z., Heo., G., Kimura, Y., McDonald-Buller, E., Allen, D., Carter, W. P. L., and Yarwood, G.: A new condensed toluene mechanism for Carbon Bond: CB05-TU, Atmos. Environ., 44, 5346-5355, 2010.

Yarwood, G., Rao, S., Yocke, M., and Whitten, G.: Updates to the Carbon Bond Chemical Mechanism: CB05, Final Report to the US EPA, RT-0400675, available at: www.camx.com, 2005. 